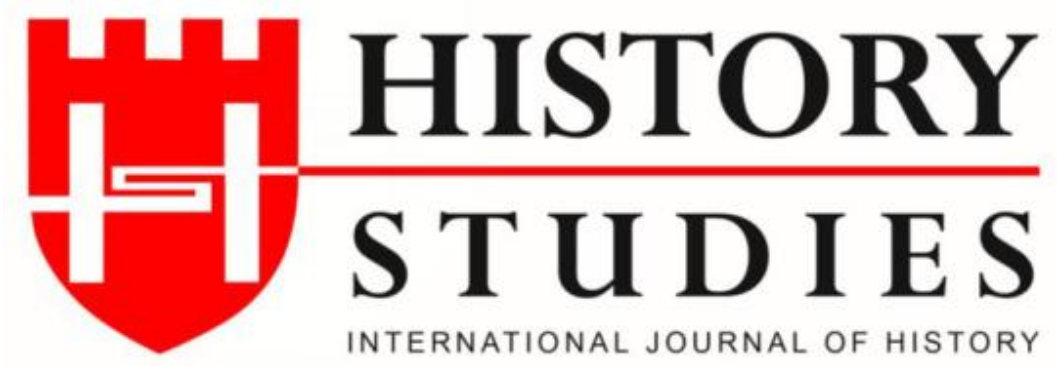

ISSN: 13094173 (Online) 1309 - 4688 (Print)

Volume 8 Issue 4, p. 33-56, December 2016

DOI Number: 10.9737/hist.2017.505

\title{
Kırım Savaşı Sırasında Osmanlı Devleti ile Müttefik Devletler Arasındaki Silah Ticareti (1854-1856)
}

The Arms Trade Between the Ottoman Empire and the Allies during the Crimean War (1854-1856)

\author{
Yrd. Doç. Dr. Mehmet ÇETiN \\ Dokuz Eylül Üniversitesi - İmir
}

Prof. Dr. Recep KÖK

Dokuz Eylül Üniversitesi

Öz: Bu çalışmada Kırım Savaşı'nda Osmanlı Devleti ile Ingiltere ve Fransa arasında gerçekleşen silah ticareti incelenerek, silah ve mühimmat ithalatının yine bu ülkelerden alınan diş borçlar ile karşılandı $\breve{g}$ tespit edilmektedir.

Anahtar Kelimeler: Osmanlı Devleti, Kırım Savaşı, Rusya, İngiltere, Fransa, silah ticareti

Abstract: This study examines the arms trade between the Ottoman Empire and G. Britain and France during the Crimean War and presents that the weapons and ammunitions imported from $G$. Britain and France were paid with the borrowed money from these countries.

Keywords: Ottoman Empire, Crimean War, Russia, France, Britain, arms trade

\section{Giriş}

Orduların silah ve mühimmat gibi savaş malzemeleri ile donatımı savaş lojistiğinin önemli bir unsurudur. Silah ve mühimmat üretiminin belirli ülkelerde ve merkezlerde yoğunlaşması, bu savaş malzemelerinin alım-satımını uluslararası ilişkilerin olduğu kadar uluslararası ticaretin de bir konusu haline getirmiştir. 19. yüzyıl Avrupası'nda uluslararası ilişkiler, uluslararası silah ticareti açısından da belirleyici olmuştur. Nitekim Kırım Savaşı bağlamında ülkelerin çıkar ilişkilerine dayalı dış politikaları, uluslararası silah ticaretine yön vermiş; akrabalık bağı ve kendince uzun vadeli siyasi çıkarları bulunduğu Rusya ile bozuşmak istemeyen Prusya, müttefiklerin yoğun baskıları sonucunda Rusya'nın Belçika'dan gerçekleştirdiği silah alımlarının nakliyesinin kendi toprakları üzerinden yapılmasına engel olmak zorunda kalmıştır. ${ }^{1}$

Literatürde Kırım Savaşı, çok geniş bir yelpazede ele alınmıştır. Silah ticaretinin çok boyutlu özelliklerine rağmen erken modern savaşlara ait dönemsel çalışmalarda olduğu gibi Kırım Savaşı'nı ele alan çalışmalar da ya askeri teknik ve taktiksel detaylarla odaklanmakta ya da kronolojik olaylar dizisi olarak savaşların siyasi tarihine yer verilmektedir. Birçok çalışmada ise savaşı askerî, siyasi yahut iktisadî olmak üzere tek bir yönüne odaklanılmaktadır. John Sweetman (1991), ilk grupta yer alan çalısmalara örnek gösterilebilir. Haritalar ve cepheden fotoğraflarla desteklenen çalışmasında Sweetman, savaşın taraflarına ilişkin detaylı bilgiler sunmaktadır. Çalışma aynı zamanda askeri taktiklere ilişkin krokiler de içermektedir. Saim Besbelli (1977) ise savaş süresince gerçekleşen deniz savaşlarını ele

${ }^{1}$ BOA (Başbakanlkk Osmanlı Arşivi) İrâde, Hariciye, (BOA. İ. HR.) 109/5348, lef. 10., 5 Haziran 1854 (1270 R 9). 
almaktadır. Çalşma büyük ölçüde ATASE'den elde edilen belgelere dayanmakta ve donanmalara ilişkin teknik ve stratejik detaylara odaklanmaktadır. Thomas ve Scollins (1991), savaşa katılan devletlerin ordu yapılanmaları ile birlikte muharebe alanlarındaki dağlımlarına kadar oldukça derin organizasyonel, taktik ve stratejik detaylar vermektedir. İkinci grup çalışmalar içerisinde ise Osmanlı arşiv kaynaklarının yanı sıra Fransız ve Rus kaynaklarına da erişme ve bu kaynaklardan istifade etme imkânı bulan Candan Badem (2010), en kapsamlı çalışma niteliğindedir. $\mathrm{Bu}$ çalışma siyasi tarih ve savaş tarihinin bir sentezi olarak büyük ölçüde savaşın geliştiği konjonktüre ve Osmanlı Devleti'nin bu konjonktür içerisinde bulunduğu konuma karşlık gelmektedir. Bu grupta yer alabilecek diğer bir çalışma da Erdoğan Keleş (2009)'dur. Bu çalışma, siyasi ve tarihsel detaylarla savaşın genelini kapsamaktadır. Bu bakımdan daha bütünsel bir yapıya sahip olduğu ifade edilebilir. David Goldfrank (1993) ise daha çok savaşı ortaya çıkaran diplomatik gelişmelere odaklanmaktadır. Bu bakımdan çalışma kendisine diplomasi tarihi alanında yer bulmaktadır. Çalışmada özellikle hegemonya mücadelesi üzerinden ortaya çıkan Batı Sorunu ve bu mücadelenin Doğu'daki tezahürü olarak ortaya çıkan Doğu Sorunu işlenmektedir. Alanında yazılmış en güncel çalışmalardan birisi olan Orlando Figes (2012) ise Kırım Savaşı'nı, dinsel motiflere dayalı tarihsel kökenleri ve kronolojik bir anlatım tarzı ile ele almaktadır.

Üçüncü grup çalışmalar içerisinde Osmanlı tarihi açısından en önemli görülebilecek çalışmalardan bir tanesi Ali Akyıldız (2007)'dir. Savaşın finansmanına dair değerli bilgiler veren çalışma, Osmanlı dış borçlanmasına ilişkin de temel kaynak niteliğindedir. Çalışmada Kırım Savaşı öncesindeki finansman araçlarına da değinilerek; savaş süresince Osmanlı finans sistemindeki dönüşüme de atıf yapılmaktadır. Neriman Ersoy Hacısalihoğlu (2007) ise Kırım Savaşı'nın Osmanlı savaş sistemine getirdiği bir yenilik olan telgraf üzerine odaklanmaktadır. Stephen Harris (2000) de savaş süresince bilgi sağlama vasitalarından birisi olan istihbarat konusunu ele almıştır. John Sweetman (1973) ise çalş̧masında savaş süresince askeri nakliyat sisteminin işlerliğini değerlendirmektedir. Bu bakımdan son grup çalş̧maların savaşa ilişkin tekil alanlarda yoğunlaştıkları ifade edilebilir. Dolayısıyla silah ticareti, büyük ölçüde savaş lojistiğinin bir bileşeni olarak lojistik faaliyetler içerisinde genel hatlarıla ele alınmaktadır. Bu durum silah ticaretine ilişkin pek çok noktanın ihmal edilmesine neden olmaktadır. Osmanlı Devleti'ne ilişkin çalş̧alarda da benzeri bir durum söz konusudur. Bunda, 19. yüzyıl öncesinde Osmanlı Devleti'nin ordusunu teçhizde, kendi kendine yeterli olması etkili olmuştur. Genel olarak belirleyici olan bir diğer unsur da orduların sayısal büyüklüğ̈̈nün devletlerin askeri gücünü ifade etmede orduların teknoloji seviyesine bağlı silah ve mühimmat ile donatılmasının önemini ikinci plana itmesidir.

$\mathrm{Bu}$ çerçevede çalışmanın amacı, ikili ittifak ilişkileri bağlamında ve Kırım Savaşı özelinde Osmanlı Devleti ile müttefik devletler arasindaki silah ticaretinin hem teknik, hem finansal ve hem de işleyiş özelliklerini ön plana çıkarmaktır. Çalışma üç bölümden meydana gelmektedir. İlk bölümde Klasik Dönem'den Kırım Savaşı'na Osmanlı harp sanayisinin gelişimi ve ordunun teçhizi hakkında bilgi verilmektedir. İkinci bölümde 19. yüzyıl Avrupası'nda silah ticaretinin ana hatları incelenmekte ve üçüncü bölümde ise müttefik devletlerin bu savaşa nasıl dâhil olduğu ve savaş süresince Osmanlı Devleti ile İngiltere ve Fransa devletleri arasında gerçekleşen silah ticareti ele alınmaktadır.

\section{Kırım Savaşı Öncesi Osmanlı Ordusu'nda Silahlanma}

Osmanlı Devleti, askerî birliklerinin yeterli donanım ve teçhizata sahip olarak orduya katılımlarının sağlanmasına oldukça önem vermekteydi. Avrupalı rakiplerinin çoğu gibi Osmanlılar da silah ve mühimmat üretimini bir kamu tekeli ilan etmiş ve silahlanmaya ilişkin 
kaynakların nakliyat ve tahsisatını kontrolleri altına almıştı. ${ }^{2}$ Ordunun ihtiyacı olan silah ve cephanenin önemli bir kısmı, devlete ait sanayi tesislerinde üretilmekteydi. Üretim, orduya ait bütün bina, kışla ve fabrika gibi gayrimenkullerin bakım, onarım ve idamesi ile ordunun ihtiyac1 olan silah ve cephane imaline ve bunların tamir ve muhafazasina hizmet eden Tophâne-i Âmire teşkilatınca gerçekleştirilmekteydi. Silah ve mühimmatın bir kısmı ise özel sektörden mübayaa yöntemi ile sağlanmaktaydı. Özel sektör çoğunlukla halk tarafindan kullanılan ürünleri imal eder, askerî birlikler ihtiyaç duymaları halinde bu ürünler, üreticiden ya askerin kendisi ya da devlet tarafından satın alınırdı. Kamu sektörü ise yalnızca orduda kullanılan ve malî güç ve teknik bilgiye dayanan harp silah ve araçlarını üretirdi. ${ }^{3}$

Birliklerin maaş ve iaşeleri bir yana, silah üretimi ve gemi yapımı, sefer maliyetlerinde neden oldukları büyük artışlar nedeniyle Erken Modern Dönem'de devletler için üstesinden gelmesi en zor sorunlardan biriydi. ${ }^{4}$ Osmanlı merkezî yönetimi, devletin savaş malzemelerine ilişkin hammadde tekelini garantiye almak için maden yataklarına sahip olan köyleri hazinenin denetimine almıştı. Osmanlı cephane ve silah sanayisinin en önemli dallarını, güherçile ve barut üretimi ile top imalatı oluşturmaktaydı. Hammadde teminini sürekli kılmak için en yaygın olarak kullanılan yöntemlerden biri ocakllk sistemiydi. ${ }^{5}$ Sistem gereğince hammadde üretimi, ocaklık köylerinde yaşayan binlerce üretici aile arasında paylaştırılmakta, devlet böylelikle muafiyetler yolu ile nakit ödeme yapmaktan kısmen kurtulmaktaydı. Köyler bu hizmetlerinin karşılığında, avârız adı verilen olağanüstü savaş zamanı vergilerinden muaf tutuluyordu. ${ }^{6}$ Tedarik sürecinin garanti altına alınmasıyla, sefer durumunda hazinenin malî sorunlarının hammadde teminine teorik olarak olumsuz bir etki yapması engellenmiş oluyordu. $^{7}$ Kendi kendine yetme ilkesiyle hareket eden devlet, ancak kendi kaynakları yetersiz kaldığında ithalat yoluna başvururdu. ${ }^{8}$

Osmanlı Devleti, silah sanayisindeki kendi kendine yeterlilik özelliğini 17. yüzyılda da büyük oranda korumuş olsa da 18. yüzyıla gelindiğinde Osmanlı silahları daha mobil Avrupa yapımı silahlara göre yetersiz kalmaktaydı. Finansal yetersizlikler, yeni teknolojinin adaptasyonunda büyük bir engel teşkil ediyordu. Yeterli miktarda barut üretilememesinin yanında kalite de düşük kalmaktaydı. Bu dönemde devlet, İsveç, Venedik ve İspanya'dan barut, Hollanda'dan ise tüfek ve tabanca ithal etti. III. Selim'in 1794 yılında yeniçerileri Avrupa tipi yeni silah ve mühimmatla donatma girişimi, askerî tesislerin yetersizliği nedeniyle başarılı olamadı. ${ }^{9}$ Bunun üzerine askerî alanda başlayan reformlara paralel olarak harp sanayi tesisleri sslah edildi. Baruthanelerin, tophanelerin ve tersanelerin modern düzeye getirilmesine

\footnotetext{
2 Mehmet Yaşar Ertaş, "Osmanlı Savaş Organizasyonunda Zorlu Bir Süreç: Ordunun Toparlanması", Türklük Araştırmaları Dergisi, S.19, İstanbul 2008, s. 224; Hans Georg Majer, "17. Yüzyllın Sonlarında Avusturya ve Osmanh Ordularmın Seferlerdeki Lojistik Sorunları", The Journal of Ottoman Studies II, Ed. Halil İnalcik-Nejat Göyünç-Heath Lowry, İstanbul 1981, s. 192; Gabor Agoston, Barut, Top ve Tüfek, Çev: Tanju Akad, Kitap Yaymevi, İstanbul 2006, s. 144.

${ }^{3}$ Gani Özden, "Osmanlı İmparatorluğu Silahlı Kuvvetlerinin Harp Sanayi Tesisleri”, Askeri Tarih Bülteni, S.22, Y.12, Şubat, Ankara 1987, s. 59; Hikmet Süer, Türk Silahlı Kuvvetleri Tarihi, Osmanlı Devri, Osmanlı - Rus Kırım Harbi Kafkas Cephesi, Genelkurmay Başkanlı̆̆ı, Ankara 1986, s. 156.

${ }^{4}$ Agoston, Barut, Top ve Tüfek, s. 20.

${ }^{5}$ Gabor Agoston, "Gunpowder for the Sultan's Army: New Sources on the Supply of Gunpowder to the Ottoman Army in the Hungarian Campaigns of the Sixteenth and Seventeenth Centuries", Turcica, S.25, 1993, s. 80; Agoston, Barut, Top ve Tüfek, s. 135.

${ }^{6}$ Majer, agm, s. 192; Agoston, Barut, Top ve Tüfek, s. 146.

7 age, s. 166.

8 Zafer Gölen, "Osmanlı Barut Üretim Merkezi: Baruthane-i Amire”, Türkler Ansiklopedisi, Ed. Hasan Celal Güzel ve diğerleri, C.10, Ankara 2002, s. 141

9 Jonathan Grant, "Rethinking Ottoman Decline: Military Technology Diffusion in the Ottoman Empire", Journal of World History, University of Hawaii Press, C.10, S.1, Spring 1999, s. $192-198$.
} 
çalışıldı. 18. yüzyılın sonundaki Rus harplerinde kaliteli barut ihtiyacını gidermek amacıyla hayvan gücü yerine su gücünü ikame eden, en yeni ve modern bir şekilde kurulan Azadlı Baruthanesi 1800 yılında işletmeye açıldı. ${ }^{10}$ Yüzyılın sonuna gelindiğinde III. Selim'in askerî reformları sayesinde Osmanlılar, silah endüstrisini modernize etmeyi başarmışlardır. Bu dönemde kalite bakımından bazı farkllıklar olsa da devlet, cephane ve silah üretiminde büyük ölçüde kendi kendine yeter duruma gelmiştir. ${ }^{11}$ II. Mahmut döneminde gerçekleştirilen reformlar, dönemin buharlı makinelere dayalı teknoloji düzeyini yakalamayı amaçlamıştır. Buna bağlı olarak Tophane, Tüfenkhane ve Vapurhane gibi kurumlarda gerçekleştirilen revizyon ile askerî sanayi tesisleri buharlı makineler ile donatılmaya çalışılmıştır. ${ }^{12}$

19. yüzyılda Osmanlı Devleti’nde ordunun donatımı, merkezî olarak yönlendirilmeye devam etmiş, temelde kendine yetme prensibi benimsenmekle birlikte ihtiyaç duyulduğunda dışarıdan da silah ithal edilmiştir. $\mathrm{Bu}$ anlamda hiçbir zaman tam bağımlılık durumu oluşmamıştır. $\mathrm{Bu}$ dönemde devletin farklı yerlerinde bulunan baruthanelerin pek çoğu kapanmıştır. III. Selim zamanında kurulan Azadlı ve İstanbul baruthaneleri ile birlikte devletin üretim merkezi başkent İstanbul olmuştur. ${ }^{13}$ Kırım Savaşı süresince de İstanbul'da bulunan baruthaneler ve Zeytinburnu fabrikası, Osmanlı ve müttefik ordularına çok miktarda barut ve mühimmat tedarik etmiştir. ${ }^{14}$

\section{Kırım Savaşı Öncesinde Avrupa'da Silah Üretim ve Transferinin Genel Görünüşü}

Kırım Savaşı öncesi uluslararası silah ticaretinin şekillenmesinde, Batı savaş sanatının tarihsel gelişimi ve özellikle de Askerî Devrim büyük ölçüde etkili olmuştur. Merkezî ulus devletlerin oluşum süreci, orduların donatımının da merkezîleşmesini içermektedir. 15. ve 16. yüzyıl silah üretim ve transferi, kapitalizmin yayılma yolu çerçevesinde büyük ölçüde İtalya ve Kuzey Avrupa ülkelerinden, önce Fransa, Rusya ve İspanya'ya, sonrasinda ise silah üretiminin taklit üzere gerçekleştirildiği Portekiz, Osmanlı Devleti, İskoçya, Macaristan, Hindistan, Japonya, Polonya ve Balkanlara doğru gerçekleşmiştir. ${ }^{15}$ Erken Modern Dönem'de Avrupa'nın birçok ülkesinde mühimmat ve cephane imalatı, devlet imalathanelerinde değil, özel işletmelerde serbest sanatkârlar tarafindan yürütülmüştür. $\mathrm{Bu}$ dönemde, özellikle günümüz Hollanda ve Belçika'sını kapsayan Alçak Ülkeler'deki yabancı üretici ve tacirlerden ithal edilen silahlar, Batılı orduların temel donatım kaynağını oluşturmuştur. Daha çok para kazanmanın yolu daha kaliteli ve bol üretim yapmaktan geçtiğinden; bu yabancı üretici ve tacirler, yeni gelişmeleri uygulamada kendi başına karar verme inisiyatifine sahip olmuştur. ${ }^{16}$

Fransız Devrimi'ni takip eden süreçte ise silah üretim ve ticareti büyük oranda yeni oluşan ulus devletlerin kontrolünde gerçekleşmiştir. 1650 - 1850 döneminde Avrupa tipi silah üretim ve ticaretinde büyük bir istikrar söz konusu olmuştur. Bu durum Avrupalı ordular tarafindan kullanılan silahların standardize edilmesine imkân vermiştir. Takip eden dönemde

\footnotetext{
${ }^{10}$ Özden, agm, s. 62- 65.

11 Gabor Agoston, “Osmanl İmparatorluğu'nda Harp Endüstrisi ve Barut Teknolojisi, 1450 - 1700”, Osmanl Ansiklopedisi, Ed. Güler Eren, C.6, Ankara 1999, s. 630 - 631.

${ }^{12}$ Gültekin Yıldı, Neferin Adı Yok (Zorunlu Askerliğe Geçiş Sürecinde Osmanlı Devleti’nde Siyaset, Ordu ve Toplum, 1826 - 1839), Kitabevi Yaymları, İstanbul 2009, s. 457 - 459.

13 Mücteba İlgürel, "Osmanlı Devleti'nde Ateşli Silahlar", Osmanlı Ansiklopedisi, C.6, Ed. Güler Eren, Yeni Türkiye Yayınları, Ankara 1999, s. 627; Muzaffer Erdoğan, "Arşiv Vesikalarına Göre İstanbul Baruthaneleri”, İstanbul Enstitüsü Dergisi, C.2, İstanbul 1956, s. 135 - 136; Gölen, agm, s. 141.

${ }^{14}$ Genelkurmay Askeri Tarih ve Stratejik Etüt Başkanlı̆̆, Türk Silahlı Kuvvetleri Tarihi $(1828-29$ Osmanlı - Rus Harbi), 3. Cilt, 5. Kisım Eki, Ankara 1978, s. 390.

${ }^{15}$ Rachel Stohl - Suzette Grillot, The International Arms Trade, Polity Press, United Kingdom 2009, s. 11.

${ }^{16}$ Salim Aydüz, 15. ve 16. Yüzylllarda Tophane-i Amire ve Top Döküm Teknolojisi, Türk Tarih Kurumu Yaymları, 7. Dizi, S.215, Ankara 2006, s. 200; Raymond James, Henry VIII's Military Revolution: The Armies of Sixteenth Century Britain and Europe, I. B. Tauris \& Co. Ltd., London 2007, s. 30.
} 
silah ticaretinin aşamalı bir şekilde özelleştirilmesi ile bu durum yavaş yavaş değişiklik göstermiştir. Savaş zamanında ihtiyaç duyulduğunda özel silah imalatçıları ilave silah ve mühimmat sağlayabilmiştir. Böylelikle silah üreticileri savaş zamanı dışında da varlıklarını muhafaza etmiş ve savaş sonrası dönemde yeni silah tasarımları ve silah ithalatı ile üretime devam etmiş ve imalatçlar arası ticari rekabet, yeni ve daha üstün silahların geliştirilmesi sürecini hızlandırmıştır. ${ }^{17}$ Piyasa ekonomisine doğru evrilen üretim süreci, silah imalatını arttırmış ve bazı merkezlerde üretim fazlasının meydana gelmesini mümkün kılmıştır. Sonuçta üretim hacmi büyümüş ve silah ticaretinde, yerel küçük işletmeler yerine toplu devlet alımları belirleyici olmaya başlamıştır. ${ }^{18}$

Uluslararası silah transferi ve üretimi konusunda Krause, devletlerin üretim sistemleri ve bu sisteme bağlı hiyerarşik konumları konusunda bir sınıflamaya gitmiştir. Devletlerin hangi askerî üretici sınıfına girdikleri konusunda 19. yüzyıla değin gerçekleşen inovasyon dalgaları ve askerî teknolojinin yayılma evreleri, belirleyici olmuştur. Buna göre 15 . yüzyıl ortasında silah üretim ve transferinin merkezi İtalya iken; 17. yüzyılın ortas1 ile birlikte başta Liége olmak üzere Alçak Ülkeler, İngiltere ve İsveç birinci sınıf üretici olarak ortaya çıkmıştır. Bu dönemde Fransa, İspanya ve Rusya ise ikinci kademe üretici ülkeler grubunu oluşturmuştur. Modern Dönem'in başında uzun süren savaşlar silsilesi Fransa'nın silah imalatında kendine yeterli olmasını engellemiştir. Buna karşın Fransa, 18. yüzyılda silah imalatında dünyanın lideri konumuna yükselmişse de 19. yüzyılın başı ile birlikte yerini İngiltere'ye kaptırmıştır. ${ }^{19}$ Göreli olarak istikrarlı politik yapısı ve geniş ticaret ağı sayesinde İngiltere, inovasyon sürecine olan hakimiyeti ve büyük ölçekli silah imalatı ile birinci kademe devlet haline gelmiştir. Nitekim 19. yüzyıla kadar Avrupa'daki silah ticareti düzensiz ve pre-endüstriyel bir yapıda gerçeklemiştir. 19. yüzyılın ilk çeyreğinde İngiltere'de devlet, üretimde kalitenin arttırılabilmesi amacıyla üretim sürecindeki konumunu, özel sektöre devretmiştir. Fransa ve Belçika ise devlete ait askerî sanayi tesisleri ile pek çok savaşta kendilerine başvurulan üretim merkezleri olmuşlardır. ${ }^{20}$

Göreli barış dönemini ifade eden 1650 - 1850 döneminde silah üretiminde mevcut merkezler konumlarını muhafaza etmiş ve bu durum silah üretimindeki yeniliklerin endüstri devrimine kadar daha yavaş bir şekilde gerçekleșmesine neden olmuştur. Bu anlamda Kırım Savaşı, silah üretim teknolojisindeki ilerlemeler konusunda da bir dönüm noktasını teşkil etmektedir. Savaş öncesinde ordularda yaygin olan yivsiz tüfekler yerlerini yivli tüfeklere bırakmıştır. Ancak savaş süresince müttefik kuvvetlere üstünlük sağlayan hızlı doldurulabilme özelliğine sahip Enfield ve Minie marka yivli tüfekler üretim yetersizliği nedeniyle ordularda ancak sınırlı bir kullanım alanı bulabilmiştir. Savaştan sonra ise yivli tüfeklerin üretimi hızla artmıştır. Dolayısıyla Endüstri Devrimi, metalürjik inovasyonlar ve buhar gücünün geliştirilmesi, silahların teknolojik gelişmişliğine imkân tanımıştır. Dahası Endüstri Devrimi uluslararası ticarete hükmeden kapitalist ekonomik sistemin yayılmasına hizmet etmiştir. ${ }^{21}$

\footnotetext{
${ }^{17}$ Armin Krishnan, War as Business: Technological Change and Military Service Contracting, Ashgate Publishing Company, England 2008, s. 12.

${ }^{18}$ Keith Krause, Arms and the State: Patterns of Military Production and Trade, Cambridge University Press, New York 1995, s. 36.

${ }^{19}$ Stohl - Grillot, age, s. 12; Krause, age, s. $25-57$.

${ }^{20}$ Richard F. Selcer, Civil War America, 1850 to 1875, Infobase Publishing, Facts on File, USA, 2006, s. 368-369; Emrys Chew, Arming the Periphery: The Arms Trade in the Indian Ocean During the Age of Global Empire, Palgrave, MacMillan, New York 2012, s. 20-21.

${ }_{21}$ Stohl - Grillot, age, s. 13-14.; Robert Henderson, "On the Thin Red Line: Loading and Firing British Muskets during the Crimean War, 1854-1856", http://www.militaryheritage.com/enfield1853.htm (ET: 28.04.2015).
} 
Osmanlı Devleti açısından ele alındığında devletin 19. yüzyılın başına kadar üçüncü kademe bir üretici olarak imalatta taklitçilik yolu ile silah üretim ve transferini gerçekleştirebildiği fakat Kırım Savaşı öncesinde giderek ithal teknoloji ve silaha bağımlı hale geldiği görülebilmektedir. ${ }^{22}$

\section{Kırım Savaşı ve Osmanlı Devleti ile Müttefik Devletler Arasındaki Silah Ticareti}

Kırım Savaşı'nın öncesindeki çeyrek yüzyıl, savaşın siyasi ve iktisadi ön koşullarını meydana getiren çok sayıda gelişmeye sahne olmuştur. Osmanlı Devleti açısından Yunanistan'ın bağımsızlığı ile sonuçlanan Rus Savaşı, sadece dört yıl sonra Ruslarla bir ittifakı ve bu doğrultuda Hünkâr İskelesi Antlaşması'nı zorunlu kılan Kavalalı Mehmet Ali Paşa isyanı, 1838 Balta Limanı Antlaşması'nın İngiltere'ye sağladığı imtiyazların Rusların Hünkâr İskelesi ile elde ettikleri kazanımların önüne geçmesi, 1839 yılında yürürlüğe konulan Tanzimat Fermanı ve Boğazlar Sözleşmesi ile Osmanlı'nın, Boğazlar üzerindeki mutlak egemenliğinin yok olması, Metternich Sistemi'nin oluşturduğu statükoya bağlı güç dengesinin 1830 ve 1848 ihtilalleri ile sarsılması, bu ihtilallerin bir sonucu olarak Macar Mülteciler Sorunu, 1851 Kutsal Yerler Sorunu, 1852 Karadağ Harekâtı ve tüm bu gelişmeler çerçevesinde şekillenen Doğu Sorunu, sonraki dönemin uluslararası ittifaklar ağını ve sosyo - ekonomik dokusunu ve Kırım Savaşı'nı ortaya çıkaran bölgesel çatışma dinamiklerini oluşturmaktadır. ${ }^{23}$

Her ne kadar Kutsal Yerler Sorunu, savaşın asıl gerekçesini oluşturuyor gibi görünse de savaşın iktisadi oyun sahasındaki yansımasını ise öncelikli olarak Tuna Havzası'ndaki tahıl ticaretinin ele geçirilmesi ve daha geniş bir perspektiften ele alındığında Hint ticaret yolunun güvenliği ve Batılı güçlerin emperyal çıkarlarının çakışması oluşturmaktadır. ${ }^{24}$ İngiltere, Rusların Osmanlı üzerindeki emellerine ulaşması yoluyla Avrupa güç dengesini kendi lehine bozma ihtimaline, İngiltere'nin doğu ticareti ve Akdeniz'deki İngiliz varlığı için büyük bir tehlike oluşturacak olması nedeniyle karşı çıkmıştır. ${ }^{25}$

Rusya'nın Prut Nehri'ni aşarak Eflak ve Boğdan'ı işgalini izleyen dönemde, İngiltere ve Fransa, gerek sefirleri vasitasıly Osmanlı Devleti nezdindeki müdahale ve yönlendirmeleriyle, gerekse Viyana Kongreleri çerçevesinde uluslararası platformlardaki girişimleri ile sürece her zaman dâhil olmuşlardır. Savaşın tek taraflı dahi olsa fiilen başlamadan önce İngiliz hükümeti, İstanbul'daki büyükelçisi Lord Stratford Canning'i yetkilendirerek 1853 yll Haziran ay1 başında Malta'da bulunan donanmasını Gelibolu açıklarındaki Beşike Körfezi'ne sevk etmiş̧ir. Kısa süre içerisinde Salamis’ten gelen Fransız donanması da İngiliz donanmasına katılmıştır. $^{26}$

İngiliz hükümetini temsilen General John Burgoyne'un İstanbul'a gelmesi, Batılı güçlerin Osmanlı Devleti'nin yanında savaşa gireceklerine dair ilk somut adım olmuştur. Burgoyne, müttefik ordular için Osmanlı Devleti topraklarında karaya çıkabilecek uygun mevkiler konusunda keşiflerde bulunmuş ve Tuna Cephesi'ndeki Osmanlı Ordusu hakkında gözlemlerde bulunmak üzere bölgeye gitmiştir. ${ }^{27} 30$ Kasım 1853 yıllında gerçekleşen Sinop

${ }^{22}$ Grant, agm, s. 182.; Krause, age, s. 49.

${ }_{23}^{23}$ Mustafa Cezar, Mufassal Osmanlı Tarihi, C.6, İskit Yayın, İstanbul 1972, s. 3016.

${ }^{24}$ Figes, age, s. 33-39.; Besim Özcan, Kırım Savaşıı'nda Mali Durum ve Tebeanın Harp Siyaseti 1853 - 1856 , Atatürk Üniversitesi Yayınları, Erzurum 1997, s. 11.

${ }^{25}$ Hüner Tuncer, Doğu Sorunu ve Büyük Güçler (1853 - 1878), Osmanlı'nın Kader Yılları, Ümit Yayıncıllk, Ankara 2003, s. 40.

${ }^{26}$ Yüzbaşı Fevzi, 1853 - 1856 Türk Rus Harbi ve Kırım Seferi, Devlet Matbaası, İstanbul 1927, s. 7; Anderson, Matthew Smith, Doğu Sorunu, 1774 - 1923, Uluslararası İlişkiler Üzerine Bir İnceleme, Çev: İdil Eser, Yapı Kredi Yaymları, İstanbul 2010, s. 142.

27 Adolphus Slade, Müşavir Paşa'nın Kırım Harbi Anıları, Çev: Candan Badem, Türkiye İş Bankası Kültür Yayınlar1, İstanbul 2012, s. 214. 
Baskını müttefik devletler tarafından meydan okuma olarak algılanmış ve Rusya'ya verilen ültimatom ile Memleketeyn'in tahliyesi talep edilmiştir. Rusların red cevabı ile birlikte İngiltere ve Fransa, Osmanlı Devleti ile Rusya'ya karşı ittifak yapmayı kararı almışlardır.. ${ }^{28}$

Müttefik devletler ile Osmanlı Devleti arasında imzalanan ittifak antlaşmasının maddeleri arasında yer almamakla birlikte savaş süresince Osmanlı Devleti'nin savaş lojistiğine ilişkin ihtiyaçları çerçevesinde gerçekleştirdiği tüm alımlar, müttefik devletlerden yapılmıştır. $\mathrm{Bu}$ bakımdan ittifak ilişkilerinin ticari ilişkileri de şekillendirdiği ifade edilebilir. Osmanlı Devleti, savaş hazırlı̆̆ bağlamında öncelikle lojistik eksiklerini tespit ederek; bunların giderilmesine yönelik tedbirler almayı hedeflemiştir. Bunun için de Rusya'ya karşı resmen savaş ilan ettiği 4 Ekim 1853 tarihinden itibaren bahar aylarına kadar hızlı bir ikmal seferberliğine girişmiştir. Bahar aylarına kadar geçen sürede ihtiyaç duyulan mühimmat ise çoğunlukla ordu mevcutlarından kullanılmıştır. ${ }^{29}$ Kırım Savaşı'nda ihtiyaç duyulan mühimmatın temini konusunda gerekli görülen mühimmat ve savaş malzemesi öncelikle önem derecesine göre sınıflandırılmış, ardından ne şekilde temin edileceği kararlaştırılmıştır. Buna göre mühimmat ve savaş malzemelerinin bir kısmının devlet mevcutlarından kullanılması, bir kısmını tüccar vasitasıyla Avrupa'dan getirtilmesi ve bir kısmının ise ülke içinde tedariki ve imali kararlaştırılmıștır. ${ }^{30}$

Dışarıdan ithal edilecek her türlü savaş malzemesinin ne şekilde tedarik edileceğinin ve fiyat ve teknik özelliklerinin belirlenmesi amaciyla Seraskerlik, Tophâne-i Âmire, Meclis-i Hass-1 Vûkela azalarından ve tüccardan bazı kimselerin tayin edilmesiyle bir komisyon teşkil edilmiştir. Komisyona katılan tacirler, savaş malzemelerinin tedarikine aracı olmayı kabul etmiş iken top, fişek ve barut gibi mühimmatın yurtdışından kendileri aracilığılla getirtilmesine, karşı çıkmışlardır. Bunun üzerine tüccar tarafından getirtilemeyen top, fişek ve barut gibi mühimmatları tedariki amaciyla Osmanlı Devleti tarafindan İngiltere ve Fransa sefaretlerine tebligatlar yazılarak; devletin bu ülkelerde bulunan sefirleriyle irtibata geçilmiştir. İngiltere ve Fransa'dan satın alınacak mühimmatın, Tophâne-i Âmire tarafından verilecek numune ve ölçülere uygun olması istenmiştir. $\mathrm{Bu}$ bakımdan dönem itibariyle silah endüstrisinde standardizasyonun tam olarak sağlanamadığı ifade edilebilir. Fransa Sefiri olan Veliüddin Rifat Paşa ve İngiltere Sefiri olan Kostaki Musurus Paşa, bu ülkelerde bulunan tüccar ile iletişime geçerek Osmanlı Devleti'nin kendilerine tanıdığı yetki çerçevesinde mühimmat ve benzeri silah malzemelerinin alımını gerçekleştirmeye çalışışlardır. ${ }^{31}$ Komisyonda alınan kararlar çerçevesinde yurtiçinden ve yurtdışından tedarik edilmesi gerekli görülen malzemelerin listesi miktarlarıyla birlikte Tablo 1'de verilmiştir. Yurtiçinden tedarik edilecek mühimmat ve çeşitli savaş malzemesinin bedeli 29 milyon kuruş olarak hesaplanmış iken yurtdışından ithal edilecek mühimmat için Hazine'den Tophane ve Harbiye namına 11.250.000 kuruşluk kredi mektubu tahsis edilmiştir. Bununla birlikte Rothschild, yurtdışından gerçekleştirilecek bakır, kurşun ve buna benzer hammadde alımında aracıllk faaliyeti ile Osmanlı Devleti'ne hizmet etmeye gönüllü olduğunu bildirmiştir. Londra'dan getirtilecek mühimmatın bedelinin Rothschild tarafından karşılanması karşılığında bazı büyük gümrüklerin

\footnotetext{
28 BOA., A. AMD. (Sadaret Amedi Kalemi) 50/43, 5 Ocak 1854 (1270 R 5); Ali Fuat Türkgeldi, Mesail-i Mühimme-i Siyasiye, C.1, Haz.: Bekir Sitkı Baykal, Türk Tarih Kurumu, Ankara 1987, s. 30 - 36; Fevzi, age, s. 29; Emin Ali Çavl, Kırım Harbi, Hilmi Kitabevi, İstanbul 1957, s. 21; Olive Anderson, "Great Britain and the Beginnings of the Ottoman Public Debt, 1854 - 55", The Historical Journal, C.7, S.1, 1964, s. 148.

${ }^{29}$ BOA., (İrade Meclis-i Mahsus) İ. MMS. 1/7, 5 Şubat 1854 (1270 Ca 7).

${ }^{30}$ BOA., (Bab-1 Ali Evrak Odas1 Ayniyat, Defter), AYN. d. No: 723., s. 23., 21 Temmuz 1854 (1270 L 25).

${ }^{31}$ BOA., (Mektubî Kalemi Nezâret ve Devâir Evrakı) A. MKT. NZD. 112/61, 22 Mart 1854 (1270 C 22); BOA., (İrade Hariciye) İ. HR. 106/5213, 25 Şubat 1854 (1270 Ca 22); BOA., İ. MMS. 1/7, lef. 18., 20 Aralk 1853 (1270 Ra 19).
}

\section{Journal of History Studies}


karşıllk gösterilmesinin veyahut mühimmat alımının taksitli olarak gerçekleştirilebilme durumunun oluşturulacak bir komisyonda kararlaştırılması uygun görülmüştür. ${ }^{32}$

Tablo 1: Yurtiçinden ve Yurtdışından Tedarik Edilmesi Kararlaştırılan Mühimmat ve Malzeme ${ }^{33}$

\begin{tabular}{|c|c|c|c|c|}
\hline \multirow[t]{2}{*}{ Eşyanın Cinsi } & \multicolumn{2}{|c|}{ Miktar } & \multirow{2}{*}{ Birimi } & \multirow{2}{*}{$\begin{array}{l}\text { Nereden Tedarik } \\
\text { Edileceği }\end{array}$} \\
\hline & Yurtiçinden & Yurtdışından & & \\
\hline Ham demir & 3.000 & 5.000 & kantar & Londra'dan \\
\hline Yassı çubuk demiri & 3.000 & 5.000 & kantar & Londra'dan \\
\hline Hartuçluk şali (bez) & 35.300 & 750.000 & zira $^{6}$ & Londra'dan \\
\hline Hartuçluk kâğıt & 1.812 & 4.500 & top & Londra'dan \\
\hline Beyaz teneke & 858 & 700 & sand1k & Londra'dan \\
\hline Sarı teneke & 2.267 & 6.750 & kıyye & $\begin{array}{l}\text { Londra'dan } \\
\text { ( } 3 \text { bini burma teneke) }\end{array}$ \\
\hline Fransız köselesi & - & 8.000 & kiyye & Marsilya'dan \\
\hline Yağlı kösele & 7.000 & 8.000 & kiyye & Marsilya'dan \\
\hline $\begin{array}{l}\text { Samanlı tabir olunur } \\
\text { eğe }\end{array}$ & 2.334 & 5.666 & deste & Triyeste'den \\
\hline İngiltere eğesi & 133 & 363 & düzine & Londra'dan \\
\hline İsfidaç & 25 & 100 & sandik & Likorna'den \\
\hline Venedik koğuşu & 8.000 & 120.000 & adet & Triyeste'den \\
\hline Muy-1 hinzır & - & 2.875 & kiyye & Fransa, İngiltere ve diğer \\
\hline Maden kömürü & 65.000 & 65.000 & kantar & Londra'dan \\
\hline $\begin{array}{l}\text { Demir top ve obüs } \\
\text { tanesi }\end{array}$ & 1.000 .000 & 2.250 .000 & kiyye & Londra'dan \\
\hline Kanaviçe kirpası & 1.000 & 500 & top & Fransa veya İngiltere'den \\
\hline $\mathrm{Kal}^{*} \hat{1}$ & - & 200 & kantar & İngiltere'den \\
\hline
\end{tabular}

\footnotetext{
${ }^{32}$ BOA., A. AMD. 50/62, 5 Şubat 1854 (1270 Ca 7); BOA., İ. MMS. 1/7, lef. 25., 29 Mart 1854 (1270 C 29).

${ }^{33}$ BOA., İ. MMS. 1 - 7., lef. 5. ve lef. 20., 23 Ocak 1854, (1270 R 23).
} 
Mehmet ÇETIN, Recep KÖK

\begin{tabular}{|c|c|c|c|c|c|}
\hline & Pik demiri & 2.000 & 60.000 & kantar & İngiltere'den \\
\hline & Köhne halat & - & 36.666 & kiyye & Ingiltere'den \\
\hline & Tokmak kayışı & - & 10.000 & top & Londra'dan \\
\hline & $\begin{array}{l}\text { Farklı türde vidalı } \\
\text { mismar }\end{array}$ & 667 & 333 & paket & Fransa'dan \\
\hline & Barut & - & 80.118 & kantar & Avrupa'dan \\
\hline & Fitil-i Misrî & - & 43.000 & kıyye & İskenderiye'den \\
\hline & Kapsül & 40.000 .000 & 40.000 .000 & adet & Avrupa'dan \\
\hline & Çakmak taşı & 25.000 .000 & 45.000 .000 & adet & Avrupa'dan \\
\hline $\begin{array}{l}\text { HISTORY } \\
\text { STUD I ES }\end{array}$ & Fişek & 30.000 & 60.000 & sandik & $\begin{array}{l}\text { Avrupa'dan sipariş } \\
\text { edilecek } \\
35 \text { bin sandık fişek ayrıca } \\
\text { gönderilecektir. }\end{array}$ \\
\hline & Çadır & - & 4.305 & adet & \\
\hline Volume 8 & Bakır kapkacak & 27.300 & 37.300 & kiyye & \\
\hline $\begin{array}{l}\text { December } \\
2016\end{array}$ & Farklı türde misketler & 55.772 & - & kantar & \\
\hline & Keçe & 17.000 & - & adet & \\
\hline & Deri & 33.000 & - & adet & \\
\hline & Kösele & 11.000 & - & adet & \\
\hline & Sepet ve küfe & 30.000 & - & adet & \\
\hline & Ihlamur dalı & 90.000 & - & adet & \\
\hline
\end{tabular}

Tablodan da görülebildiği üzere devlet, yurtdışından ithal ettiği savaşa malzemelerinin bir kısmını yurtiçinden de tedarik edebilmektedir. Bu bakımdan temel sıkıntıyı silah ve mühimmat açısından dışa bağımlılık değil; savaş nedeniyle üretim kapasitesinin kısa süre içerisinde arttırılamaması oluşturmaktadır. Yurtdışından yapılacak alımlarda en büyük kısmı kapsül, çakmak taşı, top ve obüs gibi silah ve mühimmat alımı oluşturmuş ve alımların büyük ölçüde müttefik ülkelerden gerçekleştirilmesi öngörülmüştür.

\section{a) Fransa ile Gerçekleştirilen Silah Ticareti}

Fransa'dan satın alınan savaş malzemesinin önemli bir kısmı, Fransa Savaş Bakanlığı'nın vasıtasıyla ordu ambarlarından tedarik edilmiştir. Satın alımlarda Osmanlı Devleti'nin Paris 
Sefiri olan Rifat Veliüddin ve Galata tüccarlarından Durand ve Anton ile Sarraf Rothschild aracıllk görevi üstlenmiștir. Satın alınan silah ve mühimmat, Marsilya Limanı'ndan gemilerle İstanbul'a nakledilmiştir. ${ }^{34}$ Marsilya'dan gerçekleştirilen 14 sefer sonucunda Fransa'dan Osmanlı Devleti'ne 46.032 adet tüfek içeren 1.920 kasa, 2.914 adet karabina içeren 167 kasa, 80 milyon silah kapsülü içeren 360 kasa ve 183 varil, 68 kasa silah aksesuarı, 11 kasa karabina aksesuarı, 10 bin adet çanta içeren 13 kasa gönderilmiştir. $\mathrm{Bu}$ malzeme ve ekipmanların toplam değeri 412.203 franktır. Bu da yaklaşık olarak 2.267.000 kuruş etmektedir. Bu tutara ilaveten toplam bedelin \%10'u üzerinden 41.220 frank navlun bedeli ödenmiştir. Boşaltım, hammaliye, depolama, nakliye, nöbetçi ücretleri, mavna kiraları, ruhsat, konşimento, sigorta bedelleri ve poliçe maliyetleri ile birlikte toplam bedel 468.091 frank yani yaklaşı 2.617 .856 kuruştur. Osmanlı Devleti, gönderilecek tüfeklerin yeni moda şişhane tüfekleri olmasını talep etmiş olsa da bu talep kısmen sağlanabilmiştir. Gönderilen tüfek, kapsül ve aksesuarların nakliyatı gerçekleştikçe defterleri tanzim edilerek Seraskerlik'e takdim edilmiştir. ${ }^{35}$

Fransız ordu ambarlarından satın alınan tüfeklerin her biri, yaklaşı olarak 35 frank 59 centime mal olmuş ve alet, edevat ve Marsilya'ya kadar olan nakliye ve diğer masrafları ile birlikte bu fiyat 38 frank 83 centime kadar yükselmiştir. Fransa Savaş Bakanı ile gerçekleştirilen mülakatta yeni alınacak 50 bin adet tüfeğin de aynı fiyat üzerinden alınabileceği belirtilmiştir. Bununla birlikte 1848 senesinde Fransı askerleri için sipariş edilip; sonradan vazgeçilerek fabrikatör elinde kalan 14 bin adet silahın, daha ucuz fiyatla alınabileceği, Fransa Savaş Bakanı tarafından beyan edilmiştir. Fabrikatör tarafından gönderilen numunelerin talebe uygun olması nedeniyle bu tüfeklerin satın alınmasına karar verilmiştir. Marsilya'da gerçekleşecek olan teslimata kadar tüm nakliye masrafları, fabrikatör tarafından karşlanmak üzere bu tüfeklerin bedeli toplam 205 bin franka mal olmuştur. Ödemelerin teslimatın başlamasından 6 ay sonra gerçekleştirilmesi uygun görülmüş̧ür. Gerçekleştirilen pazarlıkların sonucunda tüfeklerin tanesi için 34 frank 67 centime anlaşılmış ve tüfek başına 4 frank 16 centim olmak üzere satın alınan 14 bin tüfek için Hazine, toplam 58.240 frank indirim sağlamıştır. Fransa'dan satın alınan savaş malzemelerinde aracıllk görevi üstlenen Veliüddin Paşa, daha sonra Belçika'ya giderek Liege'deki silah atölyelerini gezmiştir. Fakat Paris'te üretilen silahların gerek fiyat ve gerek işçilik açısından daha üstün olduğunu bildirmiştir. 14 bin adet tüfeğin bedeline karşıllk Rothschild tarafından poliçe verilmesi ve poliçesinin İstanbul'a varmasından itibaren 31 gün sonra ödenmesi, Maliye Nezareti'ne havale olunmuştur. $^{36}$

Veliüddin Paşa'nın aracıllk yaptı̆̆ bir diğer alım da askerlerin kullanması için satın alınması kararlaştırılan 80 bin adet çantadır. Her bir çanta, nakliye masrafları ile birlikte birim fiyat1 11,5 franktan toplam 980 bin franka mal olmuştur. Tutarn yüksekliği ödemenin ne şekilde gerçekleştirileceği hususunda tartışmalara neden olmuş, Fransa Savaş Bakanlı̆̆ ödeme konusunda, Veliüddin Paşa vasitasıyla Seraskerlik ile irtibata geçmiştir. Çanta bedelinin ilk etapta Maliye Hazinesi'nden karşılanması düşünülmüşse de Bank of England'daki dış borç hesabından ödenmesi kararlaştırılmıştır. ${ }^{37}$

Galata'da ikamet etmekte olan Fransiz tüccarmdan Durand ve Anton da Fransa ile gerçekleştirilen silah ticaretine aracılık yapmıştır. Serasker Paşa tarafından yazılan ve Tophane Müşiri'ne havale edilen tezkire ile Fransa'dan 25 bin adet kapsüllü tüfeğin satın alınması kararlaştırılmıştır. Yapılan sözleşme gereğince tanesi 36 frank değerinde olup toplamda 900

\footnotetext{
${ }^{34}$ Nakledilen silah ve mühimmata ilişkin bilgiler Ek’teki tabloda gösterilmektedir.

${ }^{35}$ BOA., HR. SYS. 1346/54, 13 Ocak 1854 (1270 R 13); BOA., AYN. d. No: 618, s. 106., 18 Ocak 1854 (1270 R 18); BOA., A. MKT. NZD, 137/7, 8 Mart 1855 (1271 C 18).

${ }^{36}$ BOA., İ. HR. 109/5351, 31 Mart 1854 (1270 B 2); BOA., HR. SYS. 1348/46, 10 Mayı 1854 (1270 Ş 12).

${ }^{37}$ BOA., ML. MKT. d. No: 217, s. 28., 12 Temmuz 1855 (1271 L 26).
} 
bin franka mal olan bu tüfeklerin ilk etapta 5 bin adedi teslim edilecektir. Her ayın sonunda ise frankın kuruş cinsinden değeri belirlenerek gerekli iskonto veyahut zam yapılacaktır. Buna karşıllk sipariş edilen tüfeklerin, 1854 yılı Mayıs ayının sonuna kadar teslim edilmesi kararlaştırılmıştır. Tüfeklerin toplam bedeli ise ilk taksiti peşin olmak üzere toplam beş taksitte ödenecektir. Taksitlerin ödenmesinde gecikme olması durumunda tacirlere faiz talep etme hakkı tanınmıştır. Yapılacak bu harcama için hazine tarafindan bir karşılık gösterilmesi gerekirken, ilk taksitin bile ödenmesinde sıkıntı çekileceğinin ortaya çıkması üzerine ilk taksit olan 180 bin frank, zorunlu olarak \% 3 faiz ile eytam sandığından ödenmiştir. ${ }^{38}$

Fransa'dan yapılan silah alımına aracılık eden bir diğer kişi de Sarraf Rothschild olmuştur. Devletin içerisinde bulunduğu finansman sıkıntısı nedeniyle gerçekleşen pek çok alımda ödeme, Rothschild'in Fransa'da bulunan vekili tarafından gerçekleştirilerek; poliçesi Hazine-i Celile’ye gönderilmiştir. Rothschild vasıtasıyla gerçekleştirilen bazı alımlar Tablo 2'de gösterilmektedir. Tablo'da gösterilen alımların toplam bedeli 10.514.976 kuruş tutarında olup; hazine tarafindan verilen kaime ve evrak-1 nakdiye ile ödenmiştir. Ödemeler sırasında kuruşun frank değeri 16,25 centim ile 19 centim arasında değişiklik göstermiştir.

Tablo 2: Rothschild Vasitasıyla Gerçekleştirilen Silah Alımlar ${ }^{39}$

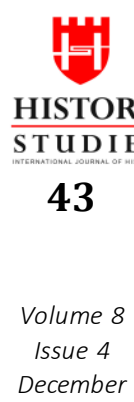

\begin{tabular}{|c|c|c|}
\hline Mühimmat & Kuruş & Ödeme Aracı \\
\hline 40 bin tüfek & $8.054 .317,2$ & \multirow{5}{*}{ Evrak-1 Nakdiye } \\
\hline 2 bin şişhane & 83.541 & \\
\hline 10 milyon fişek & $264.736,8$ & \\
\hline Her 100 frankta $\% 0,5$ komisyon & 571.184 & \\
\hline Toplam & 8.973.779 $^{40}$ & \\
\hline 50 milyon kapsül & 777.397 & \multirow{2}{*}{$\begin{array}{c}\text { Hazine-i Celile'den } \\
\text { kaime-i nakdiye olarak }\end{array}$} \\
\hline Komisyonu ile birlikte kapsüllü tüfek & 763.800 & \\
\hline Genel Toplam & 10.514 .976 & \\
\hline
\end{tabular}

Fransa Devleti'nden satın alınan mühimmat, sadece silah ve silaha ilişkin ekipmanlarla sınırlı kalmamış, ordularda kullanılmak üzere Fransa'dan 100 adet de dürbün satın alınmıştır. Bunlar, özel bir görevli nezaretinde posta vapurları vasıtasıyla İstanbul'a nakledilmiştir. Fransa Devleti, Osmanlı Ordusu bünyesinde oluşturulan Kazak birlikleri için gerekli olan silahların

\footnotetext{
${ }^{38}$ BOA., A. AMD. 50/62, 5 Şubat 1854 (1270 Ca 7); BOA., İ. MMS., 1/7, lef. 19., 29 Ocak 1854 (1270 R 29); BOA., İ. DH. 281/17655M, 3 Kasım 1853 (1270 S 1).

39 BOA., (Hâriciye Nezâreti, Paris Sefâreti Evrakı) HR. SFR.4., 10/2, 15 Ocak 1853 (1269 R 4); BOA., İ. DH. 275/17274, lef 1., 10 Temmuz 1853 (1269 L 3); BOA., A. AMD. 59/68, 1854/55 (1271).

${ }^{40} \mathrm{Bu}$ meblağın Fransa'da bulunan Osmanlı şehbenderi tarafindan poliçe çekilmek suretiyle ödenmesine çalsşılmışsa da başarılı olunamaması üzerine poliçenin çekilmesi Rothschild tarafından gerçekleştirilmiştir.
} 
bir kısmını tedarik etmiş ve Şeyh Şamil'e gönderilmek üzere de 10 bin adet çakmaklı tüfek ile 300 milyon çakmaktaşı tertip etmiştir. ${ }^{41}$

Devlet, silah alımları karşıllğında yapılacak ödemelerde ortaya çıkması muhtemel gecikmelerin itibarını zedeleyeceğini düşünerek titiz davranmaya çalısmışsa da Fransa'dan sipariş olunan mühimmatın bedelinin ödenmesinde oldukça zorlanmıștır. Fransa'dan sipariş edilen 50 bin tüfeğin ilk taksitinde 10 gün vadeli olarak keşide olunan 4 milyon kuruş değerindeki poliçenin, daha sonra ihtiyat tertibinden tedarik olunmak üzere taşra emvalinden verilmesi kararlaştırılmıştır. Fakat taşra emvalinden tahsis edilen havalelerin aylık 10 milyon kuruşa varması nedeniyle dış borçlanma gündeme gelmiştir. İlk taksit olan 4 milyon kuruşun ödenmesi konusunda, 31 Temmuz 1853 tarihinde oluşturulan komisyonda bu tutarın Hazine tarafından karşılıksız olarak ödenmesinin mümkün olmadığı ifade olunmuştur. Buna göre tüfek bedelinin ilk taksitini oluşturan 4 milyon kuruşun 1 milyonunun zahire alımı için ayrılan bedelden karşılanması, 500 bin kuruşunun poliçenin vadesi dolana kadar Hazine tarafindan tedarik edilmesi ve 2,5 milyon kuruşunun ise İstanbul sarraflarından Hoca Canik, Abraham, Ohannes ve Maksud'un devletin Dersaadet Bankası'na olan borçlarının ödenmesi amaciyla Hazine'ye sağladıkları 5 milyon kuruşun geri ödenme tarihinin 3 ay ertelenerek tüfek bedeline aktarılması suretiyle ödenmesi kararlaştırılmıştır. Kalan meblağın ve ikinci taksit olan 4,5 milyon kuruşun ödenmesi konusunda ise 3 Ağustos 1853 tarihinde bir meclis oluşturulmuştur. Bunun için de banka kurucularından borç olarak alınan 5 milyon kuruştan 2,5 milyon kuruşunun Tersane, Tophane ve Nizamiye hazinelerine tahsis edilmesi, geriye kalan 2,5 milyon kuruşun ise tüfeklerin bedeline aktarılması kararlaştırılmıştır. Kalan tutar ise eytam sandığından ödenecektir. Fransa'dan satın alınıp taksit taksit Osmanlı Devleti'ne naklolunan tüfeklerden küsur kalan 10.239 adet tüfeğin bedeli olan 1.947.412 kuruşun karşıllğgnda ise 31 gün vadeli poliçe verilmiştir. Tüfek bedeli karşıllğında verilen poliçelerden vadeleri gelip ödenemeyenler için de eytam sandığına başvurulmuştur. Bu bakımdan eytam sandığı, Osmanlı Devleti için ödenemeyen senetlerin karşılanması hususunda sık sık başvurulan bir kaynak olmuştur. $^{42}$

\section{b) İngiltere ile Gerçekleştirilen Silah Ticareti}

Kırım Savaşı döneminde İngiliz silah sanayiinde daha çok özel sektörün egemen olduğu görülmektedir. İngiltere'nin tersanesinden başka baruthane, tüfenkhane ve benzeri kamu imalathanesi olmadığından ve top, tüfek ve diğer savaş malzemeleri tümüyle ticari fabrikalarda üretildiğinden Osmanlı Devleti tarafından buradan ithal edilen mühimmat, büyük ölçüde tüccar ve fabrikatörler aracılı̆gyla tedarik edilmiştir. ${ }^{43}$ Satın alınacak olan barut ve diğer mühimmatın kaç dirhem olacağı, nasıl paketleneceği ve satın alınması düşünülen 35.000 sandık tüfek fişeğinin hangi kıstaslar çerçevesinde satın alınacağının belirlenmesi amacıyla Barutçubaşı Hoca Arekil, İngiltere'ye gönderilmiştir. Buna göre barutların 3 dirhem, kurşunların ise 7 dirhem ağırlğında olması uygun görülmüss ve satın alımda peşinat talep edilmesi durumunda poliçe yazılmasına izin verilmiştir. Gerçekleştirilecek alımlara nezaret etmek üzere Ferik Salih Paşa, 25 bin kuruş harcırah, yol parası ve görevi süresince aylık 100 sterlin maaş ile görevlendirilmiştir. ${ }^{44}$

${ }^{41}$ BOA., İ. HR. 109/5348, lef.4., 3 Mayıs 1854 (1270 Ş 5).

${ }^{42}$ BOA., A. AMD. 60/24, 1854/55 (1271); BOA., İ. DH. 275/17274, lef 2 ve 3., 7 Ağustos 1853 (1269 Za 2); BOA., A. AMD. 48/22, lef. 1, 5 Ağustos 1853 (1269 L 29); BOA., A. AMD. 48/63, 22 Ağustos 1853 (1269 Za 17); BOA., Ayniyat, Defter, No: 618., s. 22, 34, 37,104, 13 Ocak 1854 (1270 R 13); BOA., (Hâriciye Nezâreti Mektubî Kalemi) HR.MKT., 87/1, 25 Eylül 1854 (1271 M 2).

${ }^{43}$ Ceride-i Havadis, Numara: 694, 26 Haziran 1854 (1270 N 30).

${ }^{44}$ BOA., (Hâriciye Nezâreti, Londra Sefâreti Evrakı) HR.SFR3. 14/41, lef. 2., 3 Aralk 1853 (1270 Ra 2), BOA., AYNd. No: 618, s. 171., 22 Ekim 1854 (1271 M 29). 
Fişeklerin İngiltere'de üretilmesi daha pahalıya mal olacak olmakla birlikte savaş nedeniyle imalata ilişkin sözleşmenin hemen imzalanması ve fişeklerin bedeli karşıllı̆ında poliçe çekilmesi Musurus'a bildirilmiştir. Musurus, 1854 yılı Nisan ayı sonunda Tophane-i Amire'ye göndermiş olduğu şukka ile talep edilen miktarda fişeğin kısa sürede üretilmesinin oldukça zor olduğunu fakat meşhur bir fabrikatör ile anlaşılarak 4-5 ay içerisinde 35 bin sandık fişeğin üretilebileceğini ifade etmiştir. Devlet, bu fişek alımı için öncelikle Eley Brothers \& Co. firmasıyla irtibata geçmiştir. Gerçekleşen görüşme neticesinde barutun 100 libresinin 65 sterline, kurşunun bir İngiliz kantarı miktarının 25 sterline ve bin fişeğin sandığı ile birlikte toplamda 2 pound 15 shillinge mal olacağı belirlenmiştir. Firma, bu fiyatın üzerine Ordu Levazım Dairesi tarafindan fişeklerin paketlenmesi için tedarik edilecek askerî sandıkların 1.000 tanesi için 3 shiling daha ilave etmiştir. ${ }^{45}$ Sonuçta bin adet fişek (1 adet sandık) için 52 shilling 6 pence fiyatta karar kılınmıştır. Bununla birlikte firma, hammadde fiyatlarında meydana gelecek değişikliklerin maliyetlerde artış yaratması durumunda sözleşmede değişiklik yapma hakkını da saklı tutmuştur. Tüfek fişeklerinin, 5 ay içerisinde üretilmesi ve karşılığı olarak 96.250 sterlinin, 24.062 sterlin 10 shilinglik 4 taksit halinde ödenmesi kararlaştırılmıştır. Ancak Eley Brothers \& Co. firması bürokratik yazışmalar ve üretim sürecinin örgütlenmesinin neden olacağı zaman kaybı nedeniyle toplam 35 milyon tüfek fişeğinin, 9 aydan önce üretilemeyeceğini belirtmiş ve Osmanlı Devleti de bu duruma rıza göstermiştir. Eley Brothers \& Co. firması aynı zamanda 25.000 sterlinlik bir teminat ve İngiltere Devleti'nin yazıll garantisini de talep etmiștir. Teminat olarak alınan 25.000 sterlin, sözleşme bitiminde fişek parası olarak toplam bedelden düşülecektir. Fişeklerin depolanması için bir mağaza kiralanacak ve üretilen fişeklerin mağazaya nakil masrafları, Osmanlı Devleti tarafından karşılanacaktır. Ödemeler düzenli olarak gerçekleşmediği takdirde fabrikatör zarara uğrarsa zarar da, Osmanlı Devleti tarafından üstlenilecektir. Osmanlı Devleti ise satın alacağı barutun kalitesini ve teslim güvenliğini garanti altına almak amacıyla fişeklerin "Ordnance Tower Proof Powder" olarak adlandırlan en iyi kalitede ve nizami kalibrasyona sahip olmasını ve siyah, su geçirmez sandıklara yüklenmesini, dış kısmının çadır bezinden bir örtü ile kaplanarak üzerine belirgin ve göze çarpan bir şekilde siyah mürekkeple işlenmiş ay-yıldız sembolünün olduğu ahşap kasalar halinde paketlenmesini talep etmiştir. ${ }^{46}$

Fişeklerin üretiminin ve tesliminin, denetimi amaciyla atanacak uzman kişilerin onayı istenecek ve bu kişilerin tam serbesti ile çalş̧abilmeleri sağlanacaktır. Aynı zamanda sözleșmenin imzalanmasının ardından bir hafta içerisinde Eley Brothers \& Co. firması belirlenen model ve şablona uygun şekilde paketlenmiş 1 kasa fişeği, İngiltere tarafindan tahsis edilen Tilbury Fort'a teslim edecektir. Osmanlı Devleti, söz konusu denetim işinin sağlanması için Tilbury Fort Cephanesi'nin ambar memuru Mr. Knight'1 yetkilendirmiştir. Eley Brothers \& Co. firması, atanan denetleyicilerin kötü idare ve ihmallerine bağl gecikmelerin neden olacağı kayıplar için de sorumluluk üstlenmediğini belirtmiştir. ${ }^{47}$ Lord Clarendon'un başkanlığında Board of Ordnance ve Board of Treasury, satın alınan fişeklerin depolama, nakil ve ihracatını bizzat takip etmiştir. Hatta Osmanlı Devleti'nin satın alacağı fişeklerin bedeli olan 96.250 sterlinin İstanbul'da bulunan İngiliz askerlerinin ihtiyaçlarının giderilmesi karşıllğında İngiltere Kraliyet Ordusu Hazine Kurulu tarafından karşlanabileceği belirtilmiş, nihai karar Osmanlı Devleti'ne bırakılmıştır. ${ }^{48}$

\footnotetext{
${ }^{45}$ BOA., HR.SFR3. 14/41, lef. 13., 27 Ocak 1854 (1270 R 22).

46 BOA., İ. HR. 108/5310, 18 Haziran 1854 (1270 N 22); BOA., (Hâriciye Nezâreti Siyasi Kısım) HR. SYS. 1348/27, 2 Mayıs 1854 (1270 Ş 4); BOA., HR.SFR3. 14/41, lef. 42., Haziran 1854 (1270 N).

${ }^{47}$ BOA., HR.SFR3. 14/41, lef. 43., Haziran 1854 (1270 N); BOA., HR. SYS. 1349/66, 1 Ağustos 1854 (1270 Za 7).

${ }^{48}$ BOA., HR.SFR3. 14/41, lef. 4., 5 Şubat 1854 (1270 Ca 7).
}

\section{Journal of History Studies}


Sözleşme koşullarının bu şekilde belirlenmesine karşın 1854 yılının Ocak ayından Ağustos ayına kadar geçen sekiz aylık süre sonrasında Eley Brothers \& Co. firması Osmanlı Devleti'nin içerisinde bulunduğu zorunlu savaş koşullarında teslimat süresini öngörülen 5 ayda tamamlayamayacağını belirterek 9 aya çıkarmıştır. Ayrıca 1.000 adet fişek için kararlaştırılmış fiyat olan 52 shilling 6 pence karşıllğında haftada 600 - 700 binden fazla üretim yapmanın mümkün olmadığını belirterek; talebin karşılanması için inşa edilmesi öngörülen üç farklı atölye nedeniyle ortaya çıkacak nakliye masraflarından dolayı maliyetin artabileceğini ayrıca bu denli yüksek hacimli üretim nedeniyle kurşunun ve güvenilir işgücünün fiyatının da artabileceğini beyan etmiştir. Firma tarafından 1 Haziran 1854 tarihinde Musurus Paşa'ya gönderilen tebligatta ise 35 bin sandık için haftalık olarak karşılık gelen miktar olan 1 milyon fişeği üretmenin imkânsızlı̆̆ından söz edilerek; Londra'da bu sayıda fişeği bu sürede üretebilecek herhangi bir firmanın bulunmadığı ifade edilmiştir. Son olarak ise numune fişeklerin Tilbury Fort Cephanesi’ne gönderilmesinin ardından, ambar görevlisi Mr. Knight tarafindan yazılan ve daha sonra Kraliyet Laboratuvar yöneticisi J. A. Wilson tarafindan da tasdik edilen raporda, numune olarak gönderilen kasaların sözleşmede belirtilen şartlara uygun bulunmadı̆̆ı; sandıkların kısmen kalaylı raptiyeler, kısmen de demir baskı yöntemi kullanılarak kapatıldığı, sandıkların aşırı derece kirli ve tozlu olmasından dolayı temizlenmek zorunda kalındığı dolayısıyla gerekli güvenlik şartlarının sağlanmadığı ve bu koşullarda İstanbul'a nakledilmesinin imkânsız olduğu ifade edilmiştir. J. A. Wilson, sandıkların taşıdığı patlama riski nedeniyle herhangi bir devlet cephanesine de alınamayacağını bildirmiştir. ${ }^{49}$

Sonuçta Osmanlı Devleti hâlihazırda bir anlaşma içerisinde olmasına rağmen, daha uygun koşullarda fissek üretebilecek başka bir firma aramaya başlamıştır. ${ }^{50} 11$ Eylül 1854 tarihinde Manchester tüccarından Sylvester Emile Sichel tarafindan Musurus'a gönderilen mektupta Londra'da bulunan Gustave Sichel'in Osmanlı Devleti için 35 milyon fişeği tedarik edebileceği bildirilmiştir. ${ }^{51}$ Bunun üzerine devlet, Eley Brothers and Co. ile olan sözleşmesini 100 pound tazminat karşıllğında feshetmiştir. Osmanlı Devleti adına vekâleten görev yapmakta olan Musurus ile Augustus Sylvester Sichel, Sylvester Emil Sichel ve Gustavus Sichel arasinda 7 Ağustos 1854 tarihinde imzalanan sözleşmenin koşulları; fişeklerin satın alım, paketleme, denetim, depolama ve teslimat koşulları itibariyle Eley Brothers and Co. ile yapılan sözleşme ile aynı içeriğe sahiptir. Fişeklerin yine 3 Türk dirhemi barut ve 7 Türk dirhemi kurşun ile üretilmesi kararlaştırılmışır. İngiltere Kraliyet Ordusu Levazımat Daire Başkanlı̆̆’nın garantörlük ve gözetimi de devam ettirilmiştir. Eley Brothers \& Co. ile yapılan anlaşmanın aksine 21.000 sterlin gibi daha düşük bir teminat bedeli belirlenmiştir. ${ }^{52}$

Fişeklerin toplam bedeli olan 84 bin poundun 5 bin poundu, Osmanlı Devleti tarafindan Osmanlı ülkesindeki İngiliz Ordusu'na tedarik edilen kömürün karşıllğı olarak verilmiş, kalan tutar ise Osmanlı Devleti'nin 1854 borçlanmasından karşılanmak üzere taksitlendirilmiştir. ${ }^{53}$ Üretilecek fişeklere ilişkin her iki firma ile imzalanan sözleşmeler uyarınca satın alma koşulları, Tablo 3'te gösterildiği gibidir. Tablodan da görülebildiği üzere Sichels, Eley Brothers \& Co.'ya göre yaklaşı 2,5 ay daha kısa süre içerisinde ve daha ucuza üretim yapmayı taahhüt etmektedir.

\footnotetext{
${ }^{49}$ BOA., HR.SFR3. 14/41, lef. 13., lef. 50, lef. 51, lef. 54., 7 Eylül 1854 (1270 Z 14).

${ }^{50}$ BOA., HR.SFR3. 14/41, lef. 48., 15 Ağustos 1854 (1270 Za 21).

${ }^{51}$ BOA., HR.SFR3. 14/41, lef. 55., 11 Eylül 1854 (1270 Z 18).

52 BOA., HR.SFR3. 16/27, lef. 4., 7 Ağustos 1854 (1270 Za 13); BOA., (Maliye Nezareti Mektubî Kalemi Defter) ML. MKT. d. No: 217, s. 34.

${ }^{53}$ BOA., ML. MKT. d. No: 217, s. 34., 27 Ekim 1855 (1272 S 15).
} 
Mehmet ÇETIN, Recep KÖK

Tablo 3: İngiltere'den Satın Alınan Tüfek Fişeklerinin Satın Alma Koşulları ${ }^{54}$

\begin{tabular}{|c|c|c|c|c|}
\hline & & & Eley Brothers \& Co. & Sichels \\
\hline & $\begin{array}{l}\text { Üretilecek } \\
\text { (Adet/Kas }\end{array}$ & Tüfek Fişeğinin Miktarı & $\begin{array}{l}35 \text { milyon adet } \\
35.000 \text { kasa }\end{array}$ & $\begin{array}{l}35 \text { milyon adet } \\
35.000 \text { kasa }\end{array}$ \\
\hline & Toplam B & $\operatorname{del}(\mathfrak{f})$ & 96.250 Sterlin & 84.000 Sterlin \\
\hline & Taksit & & 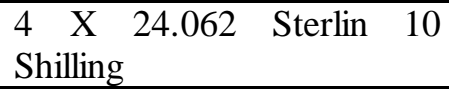 & 4 X 21.000 Sterlin \\
\hline & Birim Fiy & (1.000 Kasa) & 52 Shilling 6 Pence & 48 Shilling \\
\hline & Vade & & 9 ay & 6 ay 15 gün \\
\hline & Teminat & 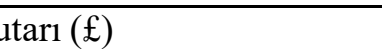 & 25.000 Sterlin & 21.000 Sterlin \\
\hline & & İlk 8.750 Kasa & $0-3$ ay & 8. hafta \\
\hline & Teslimat & İkinci 8.750 Kasa & $3-5$ ay & 14. hafta \\
\hline & Planı & Üçüncü 8.750 Kasa & $5-7$ ay & 21. hafta \\
\hline & & Dördüncü $8.750 \mathrm{Kasa}$ & $7-9$ ay & 28. hafta \\
\hline & & & $\begin{array}{l}4 \text { X } 21.062 \text { Sterlin } \\
10 \text { Shilling }\end{array}$ & 4 X 21.000 Sterlin \\
\hline $\begin{array}{l}\text { HUy } \\
\text { IISTORY } \\
\text { TUDIES }\end{array}$ & Ödeme P & & $\begin{array}{l}\text { Her bir kısmın karşılığı olan } \\
24.062 \text { Sterlin } 10 \text { Shilling bir } \\
\text { sonraki kısmın } \\
\text { hazırlanmasından sonra } \\
\text { ödenecektir. }\end{array}$ & $\begin{array}{l}\text { Her bir kısmın karşılı̆ı olan } \\
21.000 \text { Sterlin, ilgili kısmın } \\
\text { denetim onayından } \\
\text { geçmesinin ardından } 3 \text { gün } \\
\text { içerisinde ödenecektir. }\end{array}$ \\
\hline 47 & Gerçekleş & n Ödemeler & 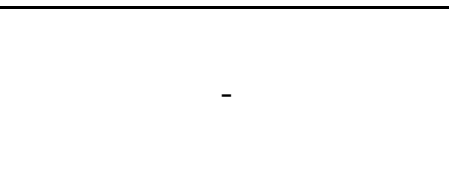 & $\begin{array}{l}\text { - } 25 \text { Ekim } 1854 \\
-16 \text { Aralik } 1854 \\
-\quad 6 \text { Şubat } 1855 \\
-21 \text { Nisan } 1855\end{array}$ \\
\hline
\end{tabular}

Sichels tarafından üç sandık fişek numune olarak, Tilbury Fort Cephaneliği'ne gönderilmiş ve bu sandıklar, Kraliyet Topçu Sınıfi'ndan Burrows isimli bir yüzbaşı tarafından denetlenmiştir. $\mathrm{Bu}$ numunelerden beğenilenler İstanbul'a gönderilmiş ve üretimin beğenilen sandıktaki fişekler baz alınarak yapılması istenmiştir. Fişeklerin denenmesi amacıyla 50 kadem uzakta bulunan bir sehpa üzerine konulan çerçeveye atış yapılmıştır. Barutları eksik olan, numunesine uymayan ve rutubetli olan sandıklar fabrikatörlere iade edilmiștir. Fișeklerin üretimi, Northfleet'teki Schlesinger and Wells fabrikasında gerçekleştirilmiş ve üretilen fişekler Tilbury Fort Cephanesi'ne depolanmıştır. Tilbury Fort Cephane görevlisi Mr. Knight'a fişeklerin depolanma, yerleştirilme ve yeniden gemilere yüklenerek sevk edilmesi esnasındaki hizmet ve kişisel harcamaları için toplam 20 sterlin 11 shilling 4 pence ücret ödenmiștir. ${ }^{55}$ Satın alınan fişeklerin denetim ve cephaneye yerleştirilmesine ilişkin masraflar, Tablo 4'te gösterilmiştir. Buna göre maliyetler; personel ücretleri ile muayene ve denetleme sürecine ilişkin olmak üzere iki gruptan meydana gelmektedir. İlk grup maliyetler toplamda 48 sterlin 12 shilling ve 10 pencetir. İkinci grup maliyetler ise 18 sterlin, 10 shilling ve 9 pence olup toplam maliyet 67 sterlin 3 shilling ve 7 pence tutarındadır.

${ }_{55}^{54}$ BOA., HR.SFR3. 14/41, 11 Eylül 1854 (1270 Z 18); BOA., HR.SFR3. 16/27, 7 Ağustos 1854 (1270 Za 13).

55 BOA., HR.SFR3. 16/27, lef. 61., 21 Mayıs 1855 (1271 N 4); BOA., HR.SFR3. 16/27, lef. 81., 10 Eylül 1855 (1271 Z 27). 
Tablo 4: Satın Alınan Mühimmatın Depolanmasına İlişkin Masraflar ${ }^{56}$

\begin{tabular}{|l|l|l|r|}
\hline \multicolumn{1}{|c|}{ Masraf Kalemleri } & Günlük Ücret & Gün & \multicolumn{1}{|c|}{ İngiliz Lirası } \\
\cline { 2 - 4 } & Shilling, Pence & & Sterlin, Shilling, Pence \\
\hline Fıçıcı ücreti & 4,1 & 20,25 & $4,2,8$ \\
\hline Sivil Personel & 2,4 & 218 & $25,8,8$ \\
\hline Askeri Personel & 9 Pence & 508,75 & $19,1,6$ \\
\hline Toplam & & $\mathbf{4 8 , 1 2 , 1 0}$ \\
\hline Tren ve Buharlı Gemi Ücretleri & $4,15,6$ \\
\hline 45 Günlük Askeri Personel Hizmeti & $1,13,9$ \\
\hline Musurus Paşa için Nisan ve Mayıs ayı Ödenekleri & $2,0,8$ \\
\hline Bir Adet Pantolon Ücreti & $1,0,0$ \\
\hline Toplam & $\mathbf{1 1 , 1 4 , 3}$ \\
\hline Yüzbaş1 Burrows'un Hesabından Düşülen & $-2,3,16$ \\
\hline Kalan & $9,0,9$ \\
\hline Osmanlı Hükümeti Tarafından Ödenecek Tutar & $6,15,9$ \\
\hline Sichel Tarafindan Ödenecek Tutar & $\mathbf{1 3 , 1 2 , 3}$ \\
\hline Yüzbaş1 Burrows'tan Alınan & $2,5,0$ \\
\hline Muayene ve denetlemeye yardımc1 personel ücreti & \\
\hline Yüzbaş1 Burrows'un Seyahat Ücretleri & \\
\hline Toplam & \\
\hline
\end{tabular}

Topçu Yüzbaşı Burrows'un 21 Mayıs 1855 tarihinde Woolwich'ten İngiltere Ordu Levazım Daire Başkanlığı'na gönderdiği tebligatta tüm fişeklerin üretilerek sözleşmenin sona erdirilmiş olduğu ve fişeklerle ilgili yaşanan tek sıkıntının üretilen fişeklerin çakmaklı tüfeklere uygun olması nedeniyle yaşandığı bildirilmiştir. ${ }^{57} 12$ Şubat 1855 tarihinde Tophane Müşiri tarafından Sadaret'e yazılan tezkirede ise satın alınan 35 bin kasadan tüccar gemisi ile

${ }^{56}$ BOA., HR.SFR3. 16/27,lef. 52., 10 Mayıs 1855 (1271 Ş 22); BOA., HR.SFR3. 16 - 27, lef. 56., 14 Nisan 1855 (1271 B 26)

${ }^{57}$ BOA., HR.SFR3. 16/27, lef. 64., 8 Haziran 1855 (1271 N 22). 
İstanbul'a nakledilmiş olan ilk parti 10 bin 50 sandık fişeğin talep edilen fişeklerle aynı olmadığı ifade edilmiştir. Karşılığında yüklü miktarda para ödenmiş olduğundan numunesine uymayan fişeklerin geçici olarak Harbiye Ambarı'na depolanması uygun görülmüştür. ${ }^{58}$ Buna göre sözleşmenin imzalanmasının ardından öngörülen süre içerisinde üretilen fişeklerin teslimatı başarıyla gerçekleştirilmiştir.

Osmanlı Devleti'nin İngiltere'den gerçekleştirdiği silah ve mühimmat alımlarında önemli bir tedarik kanalını da tacirler oluşturmuştur. Tacir Hanson vasitasılyla Avrupa'dan satın alınması gerekli görülen 58.600 kantar barutun İngiltere'den satın alınması kararlaştırılmıştır. ${ }^{59}$ Hanson'un hesabına olarak gönderilen baruta ilişkin detaylar Tablo 5'te gösterilmiştir. Satın alınan barut: top barutu, ince barutu ve vapur barutu olmak üzere üç sinıftır. Toplam alınacak barut miktarı 5.860 varil olup, her varil 35 okka 130 dirhem ağıllı̆ındadır. Her bir varil 100 sterlin üzerinden hesaplandı̆̆ında satın alınan barutun toplam bedeli 58.600 sterlin değerindedir.

Tablo 5: Hanson Bezirgan Marifetiyle İngiltere'den Satın Alınan Barut ${ }^{60}$

\begin{tabular}{|l|c|}
\hline Her bir varil 100 sterlin (35 kıyye 130 dirhem) & Siyah Barut (varil) \\
\hline Top barutu & 1.690 \\
\hline İnce barut & 1.170 \\
\hline Şehr-i Sultan isimli vapura yüklenecek barut & 3.000 \\
\hline Toplam & 5.860 \\
\hline Toplam (Sterlin) & $\mathbf{5 8 . 6 0 0}$ \\
\hline
\end{tabular}

Hanson aracılı̆ı ile satın alınıp, İngiltere'den tedarik edilen ve her bir varili, 35 okka 130 dirhem olan barutun birim varil fiyatı, 3 sterlin 19 şiline mâl olmuş fakat pazarliklar neticesinde bu fiyat 3 sterlin 18 şiline çekilmiştir. Bir sterlinin kuruş karşllğ 1 olan 134 kuruştan hesaplandığında toplam maliyet, 3.134.554,5 kuruş tutmuştur. Bu bedelin üçte birinin teslimatta, kalanının ise birer ay vade ile ödenmesi sözleşmeye bağlanmıştır. Sözleşme, sterlinin değerindeki değişmelere bağlı olarak toplam fiyatta ortaya çıkacak artış ya da azalışları telafi edecek şekilde düzenlenmiştir. Barutların konulması için yeterli sayıda varilin bulunamaması üzerine atık variller, üzerlerine bakır çemberler vurulmak suretiyle kullanılmıştır. Fakat 58.600 kantar baruttan ancak 5.900 kantarının teslimi gerçekleştirilebilmiştir. Teslim edilen kısmın bedeli evrak-1 cedide-i muvakkateden ödenmiştir. Sipariş edilen teslimatın tümüyle gerçekleştirilememesi ve İstanbul Baruthanesi'nde kullanılan makinenin gece ve gündüz sürekli olarak çalışmasından dolayı eskimesi üzerine Barutçubaşı Begos, barut imal eden bir makine almak üzere Londra'ya gönderilmiştir. Satın alınan beş dibekli makine, mevcut makinelere kıyasla yarı yarıya daha az kömür tüketmektedir. Dibeklerinin demir olması nedeniyle daha pahalı olan mermer dibeklerin kullanılmasına gerek kalmayacaktır. Üretim sürecinin her anında başına bekleyen bir ameleye de ihtiyaç duyulmamaktadır. Satın alınan makinenin bedeli olan 15.500 sterline karşıllk 8.000 sterlin değerinde bir kredi mektubu verilmiştir. Begos'a aynı zamanda Londra'dan her biri 30 okkalk olmak üzere toplam 12.000 varil yani 6.818 kantar barut satın alması da sipariş edilmiştir. Satın alınacak barutun bedelinin, Mısır vergisinden dış borç için ayrılan meblağdan

\footnotetext{
${ }^{58}$ BOA., (İrade Dahiliye) İ. DH. 314/20237, 12 Şubat 1855 (1271 Ca 24).

${ }^{59}$ BOA., (Sadâret Mektubî Kalemi Mühimme Evrakı) A. MKT. MHM. 71/9, 8 Haziran 1855 (1271 N 22).

${ }^{60}$ BOA., İ. DH. 299/18890, 11 Nisan 1854 (1270 B 14).
} 
karşılanması kararlaştırılmış ve 1854 istikrazından bu satın alım için 35.088 sterlin ayrılmıştır. ${ }^{61}$

Sefaretler ile gerçekleştirilen görüşmeler sonucunda İngiltere'den ithal edilecek silah ve mühimmatın bedeline karşıllk uzun vadeli bir poliçenin verilmesi kararlaştırılmıştır. Poliçeye karşllk ödenmesi gereken tutar ise haftalara taksim edilmiştir. ${ }^{62}$ Bununla birlikte savaş nedeniyle şiddetli finansal kaynak ihtiyacma, olumsuz koşullar nedeniyle düşük ihraç bedelli ve yüksek faizli borçlanma tekliflerinin ve savaşın devam edip etmeyeceğindeki belirsizliğin uluslararası finansal piyasalarda yarattığı kararsızlı̆ıı da eklenmesi, Osmanlı Devleti için yurtdışından yapılacak silah ve mühimmat ithalinde ciddi sikıntılar doğurmuştur. Devlet bu noktada müttefiklerinin desteğini talep etmek zorunda kalmıştır. ${ }^{63}$ Ayrıca Merkezî Hazine'den silah ve mühimmat ithali için ayrılan paranın yeterli gelmemesi, hazinenin içerisinde bulunduğu olumsuz koşullar ve eyalet vergilerinin askerî harcamalara havale edilmiş olması nedeniyle İngiltere'den tedarik edilen savaş malzemelerinin finansmanında, masrafların bir kısmının İstanbul'daki İngiliz Ordusu'nun bir takım iaşe ve levazım masraflarına karşılık mahsup edilmesi kararlaştırılmıştır. Devlet, İngiliz donanması vapurları için tedarik edilen kömürün bedeli olan 5.000 sterlini de İngiltere'den satın aldığı tüfek fişeklerinin bedelinden mahsup etmiştir. ${ }^{64}$

\section{Sonuç}

Klasik Dönem'de Osmanlı Devleti'nin ordularını teçhiz ve donatımdaki temel prensibi kendine yeterlilik olmuştur. Devlet bunu 19. yüzyıl başında hayata geçirdiği reform ve yeniliklerle de belirli ölçüde sürdürebilmiştir. 19. yüzyllın ortalarına gelindiğinde Endüstri Devrimi'nin silah imalatı üzerindeki etkilerinin ortaya çıması, Batılı devletler ile Osmanlı Devleti arasındaki teknolojik kapasite farkının açılmaya başlamasına neden olmuştur. $\mathrm{Bu}$ durum kendisini öncelikle Kırım Savaşı'nda göstermiştir. Bununla birlikte söz konusu farkın nitelikten ziyade nicelikten kaynaklandığı görülmektedir. Kırım Savaşı nedeniyle yeterli miktarda silah ve mühimmatın üretimini, askerî tesislerinde kısa süre içerisinde gerçekleştiremeyen Osmanlı Devleti, yurtdışndan savaş malzemesi ithal etmek zorunda kalmıştır. İthal edilen malzemelerin bir kısmı yurtiçi piyasadan da temin edilebilmiştir. Devlet, gerçekleştirdiği silah ve mühimmat ithali ile bu savaşta ordusunu en yeni silah ve ekipmanla donatabilmiş, barut üretmek için yurtdışından son model makineleri ve yeni icatları ithal ederek üretim sürecine entegre edebilmiştir. Bu bakımdan Kırım Savaşı özelinde devletin üçüncü kademe bir üretici olma özelliğini sürdürdüğü ve bu yolla teknoloji transferinin niteliğinin muhafaza edildiği ifade edilebilir. Dolayısıyla teknolojik alt yapı ve donanım anlamında Batılı devletler ile ortada büyük bir farkın bulunmadığı ve askerî üretim anlamında ithal teknolojiye tam anlamıyla bir bağımlılık durumunun oluşmadığı görülmektedir.

Müttefik devletlerle imzalanan ittifak antlaşmasında somut bir şekilde belirtilmemiş olmakla birlikte yurtdışından ithal edilen diğer tüm lojistik gereksinimlerde olduğu gibi silah ve mühimmat ithalinde de müttefik ülkeler tercih edilmiştir. Bunda uluslararası politik konjonktür de etkili olmuştur. Tedarik süreci ise bu ülkelerin ekonomik yapıları tarafindan şekillenmiş̧ir. Bu bakımdan İngiliz ekonomisinde egemen olan piyasa sistemi, askerî üretimde

\footnotetext{
${ }^{61}$ BOA., A. MKT. MHM. 71/9, 8 Haziran 1855 (1271 N 22); BOA., İ. DH. 299/18890, 20 Nisan 1854 (1270 B 22); BOA., İ. DH. 306/19470., 13 Ağustos 1854 (1270 Za 19); BOA., AYN. d. No: 618, s. 188., 9 Haziran 1855 (1271 N 23).; BOA., İ. DH. 313/20163., 22 Ocak 1855, (1271 Ca 3); BOA., ML. MKT. d. No: 217, s. 3.

${ }^{62}$ BOA., İ. MMS. 1/7, lef. 25., 29 Ocak 1854 (1270 R 29).

${ }^{63}$ BOA., (Sadâret Mektubî Kalemi Umum Vilâyât Evrakı) A. MKT. UM. 165/50, 1853/54 (1270).

${ }^{64}$ BOA., A. AMD. 50/63, 5 Şubat 1854 (1270 Ca 7); BOA., İ. MMS. 1/7, lef. 25., 29 Ocak 1854 (1270 R 29); BOA., İ. DH. 281/17655M, 3 Kasm 1853 (1270 S 1); BOA., HR.SFR3. 16/27, lef. 34., 26 Şubat 1855 (1271 C 8).
} 
de kendisini göstermiş ve bu ülkeden yapılan silah ve mühimmat ithalatı, fabrika ve ticari işletmeler vasıtasıyla gerçekleştirilmiştir. $\mathrm{Bu}$ durum tedarik sürecinin uzamasına ve süreç üzerindeki denetimin aksamasma neden olmuştur. Fransa'da ise kamunun ekonomideki ağırlı̆ı ve askeri malzeme üretimindeki hâkimiyeti, tedarik sürecinin daha sağlkkl bir şekilde işlemesine imkân vermiștir. İthal edilen silah ve mühimmatın tedariki sürecinde Osmanlı Devleti'ni en fazla zorlayan husus içerisinde bulunduğu finansal çıkmaz nedeniyle ortaya çıkan ödeme güçlügü olmuştur. Devlet, tarihinde ilk defa aldığı dış borç dâhil pek çok alternatif finansman yöntemine başvurmak zorunda kalmış; birçok ödeme uluslararası sarraflar tarafından çekilen poliçeler ile gerçekleştirilmiştir. Dış borçlanmanın giderek gecikmesi ile birlikte kamu kaynaklarının önemli bir kısmının ithal edilecek silah ve mühimmatın finansmanına kanalize edilmesi, savaş masraflarına ilişkin tahsisatta tıkanmalara sebebiyet vermiştir. Son olarak Osmanlı Devleti ile müttefik devletler arasında gerçekleşen silah ticaretinin, ticari kazanç motifleri tarafindan şekillendirilmiş bir siyasi tercihin ürünü olduğu da düşünülebilir. Zira devlet, İngiltere ve Fransa'dan borçlanma ile elde ettiği ve bu devletlerin öncülügünde kurulan komisyonlar vasitasıyla harcayabildiği gelirin önemli bir kısmını yine savaş malzemesi alımıyla bu ülkelere aktarmıştır.

\section{Kaynakça}

\section{Türkiye Cumhuriyeti Başbakanlık Osmanlı Arşivi}

Bab-1 Ali Evrak Odas1, Ayniyat, Defter, (AYN. d.) No: 618, No: 723.

Sadâret Amedi Kalemi (A. AMD.)

Sadâret Mektubî Kalemi Mühimme Evrakı (A. MKT. MHM.)

Sadâret Mektubî Kalemi Nezâret ve Devâir Evrakı (A. MKT. NZD.)

Sadâret Mektubî Kalemi Umum Vilâyât Evrakı (A. MKT. UM.)

Hâriciye Nezâreti Mektubî Kalemi (HR. MKT.)

Hâriciye Nezâreti, Londra Sefâreti Evrak1 (HR. SFR3)

Hâriciye Nezâreti, Paris Sefâreti Evrakı (HR. SFR4)

Hâriciye Nezâreti Siyasi Kısım, 1346, 1348, 1349. (HR. SYS.)

İrâde Dâhiliye (İ. DH.)

İrâde Hariciye (İ. HR.)

İrâde Meclis-i Mahsus (İ. MMS.)

Maliye Nezareti Mektubî Kalemi Defter No: 217.(ML. MKT. d.)

\section{Gazete:}

Ceride-i Havadis

Kitap ve Makaleler:

AGOSTON, Gabor, "Gunpowder for the Sultan's Army: New Sources on the Supply of Gunpowder to the Ottoman Army in the Hungarian Campaigns of the Sixteenth and Seventeenth Centuries", Turcica, S.25, 1993, s. 75-96.

AGOSTON, Gabor, “Osmanlı İmparatorluğu'nda Harp Endüstrisi ve Barut Teknolojisi, 1450 - 1700", Osmanl Ansiklopedisi, Ed. Güler Eren, C.6, Ankara 1999, s. 621632.

\section{Journal of History Studies}


AGOSTON, Gabor, Barut, Top ve Tüfek, Çev: Tanju Akad, Kitap Yayınevi, İstanbul 2006.

AKYILDIZ, Ali, “Osmanlı Devleti’nin Kırım Savaşı’nı Finansmanı: İç ve Dış Borçlanmalar", Savaștan Barıșa 150. Yılında Kırım Savașı ve Paris Antlașması (1853 - 1856) Bildiri Kitapçı̆̆ı, İstanbul Üniversitesi Edebiyat Fakültesi, İstanbul 2007, s. 11-18.

ANDERSON, Olive, "Great Britain and the Beginnings of the Ottoman Public Debt, 1854 - 55", The Historical Journal, C.7, S.1, 1964, s. 47-63.

AYDÜZ, Salim, 15. ve 16. Yüzyllarda Tophâne-i Âmire ve Top Döküm Teknolojisi, Türk Tarih Kurumu Yayınları, VII. Dizi, S.215, Ankara 2006.

BADEM, Candan, The Ottoman Crimean War: 1853 - 1856, (Ottoman Empire and Its Heritage), Leiden, Boston: Brill Academic Publishers, 2010.

BESBELLİ, Saim, 1853 - 1856 Osmanl - Rus ve Kırım Savaşı Deniz Harekâtı, Genelkurmay Basimevi, Ankara 1977.

CEZAR, Mustafa, Mufassal Osmanlı Tarihi, C.6, İskit Yayını, İstanbul 1972.

CHEW, Emrys, Arming the Periphery: The Arms Trade in the Indian Ocean During the Age of Global Empire, Palgrave, New York 2012.

ÇAVLI, Emin Ali, Kırım Harbi, Hilmi Kitabevi, İstanbul 1957.

DELAFIELD, Major Richard, Report on The Art of War in Europe, 1854, 1855 and 1856, Washington 1860.

ERDOĞAN, Muzaffer, "Arşiv Vesikalarına Göre İstanbul Baruthaneleri”, İstanbul Enstitüsü Dergisi, C.2, İstanbul 1956, s. 115-138.

ERTAŞ, Mehmet Yaşar, "Osmanlı Savaş Organizasyonunda Zorlu Bir Süreç: Ordunun Toparlanması", Türklük Araştırmaları Dergisi, S.19, İstanbul 2008, s. 211-233.

FIGES, Orlando, Kırım: Son Haçlı Seferi, Çev: Nurettin Elhüseyni, Yapı Kredi Yayınları, İstanbul 2012.

Genelkurmay Askeri Tarih ve Stratejik Etüt Başkanlığı, Türk Silahlı Kuvvetleri Tarihi (1828 - 29 Osmanl -Rus Harbi), 3. Cilt, 5. Kısım Eki, Ankara 1978.

GOLDFRANK, David, The Origins of the Crimean War (Origins Of Modern Wars), Routledge, 1993.

GÖLEN, Zafer, "Osmanlı Barut Üretim Merkezi: Baruthane-i Amire”, Türkler Ansiklopedisi, Ed. Hasan Celal Güzel ve diğerleri, C.10, Ankara 2002, s. 136144.

GRANT, Jonathan, "Rethinking Ottoman Decline: Military Technology Diffusion in the Ottoman Empire", Journal of World History, University of Hawai Press, C.10, S.1, Bahar 1999, s. 179-201.

HACISALIHHOĞLU, Neriman Ersoy, “Kırım Savaşı'nda Haberleşme: Varna Telgraf Hattı Şebekesi”, Savaştan Barışa: 150. Yıldönümünde Kırım Savaşı ve Paris Antlaşması (1853- 1856), 22-23 Mayıs 2006, Bildiriler, İ.Ü.E.F. Tarih Araştırmaları Merkezi Yayınları, İstanbul 2007, s. 119-130. 
HARRIS, Stephen M., British Military Intelligence in the Crimean War, 1854-56, Frank Cass \& Co., London 2000.

HENDERSON, Robert, "On the Thin Red Line: Loading and Firing British Muskets During the Crimean War, 1854-1856", http://www.militaryheritage.com/enfield1853.htm (ET: 28.04.2015).

İLGÜREL, Mücteba, “Osmanlı Devleti'nde Ateşli Silahlar”, Osmanlı Ansiklopedisi, C.6, Ed. Güler Eren, Yeni Türkiye Yayınları, Ankara 1999, s. 605-611.

JAMES, Raymond, Henry VIII's Military Revolution: The Armies of Sixteenth Century Britain and Europe, I. B. Tauris \& Co. Ltd., London 2007.

KELEŞ, Erdoğan, Osmanl, İngiltere ve Fransa İlişkileri Bağlamında Kırım Savaşı, (Ankara Üniversitesi SBE, Yayımlanmamış Doktora Tezi), Ankara 2009.

KRAUSE, Keith, Arms and the State: Patterns of Military Production and Trade, Cambridge University Press, New York 1995.

KRISHNAN, Armin, War as Business: Technological Change and Military Service Contracting, Ashgate Publishing Company, England 2008.

MAJER, Hans Georg, "17. Yüzyılın Sonlarında Avusturya ve Osmanlı Ordularmın Seferlerdeki Lojistik Sorunları", The Journal of Ottoman Studies II, Ed. Halil İnalcık, Nejat Göyünç ve Heath Lowry, İstanbul 1981, s. 185-194.

ÖZCAN, Besim, Kırım Savaşı'nda Mali Durum ve Tebeanın Harp Siyaseti 1853 - 1856, Atatürk Üniversitesi Yayınları, Erzurum 1997.

ÖZDEN, Gani, "Osmanlı İmparatorluğu Silahlı Kuvvetlerinin Harp Sanayi Tesisleri”, Askeri Tarih Bülteni, Y.12, S.22, Ankara 1987.

SELCER, Richard F., Civil War America, 1850 to 1875, Infobase Publishing, USA 2006.

SLADE, Adolphus. Müşavir Paşa'nın Kırım Harbi Anıları, Çev: Candan Badem, Türkiye İş Bankası Kültür Yayınları, İstanbul 2012.

SMITH, Matthew Anderson, Doğu Sorunu, 1774 - 1923, Uluslararası Illişkiler Üzerine Bir İnceleme, Çev: İdil Eser, Yapı Kredi Yayınları, İstanbul 2010.

STOHL, Rachel - Suzette Grillot, The International Arms Trade, Polity Press, United Kingdom 2009.

SÜER, Hikmet, Türk Silahl Kuvvetleri Tarihi, Osmanlı Devri, Osmanlı - Rus Kırım Harbi Kafkas Cephesi, Genelkurmay Başkanlığı, Ankara 1986.

SWEETMAN, John, "Military Transport in the Crimean War", English Historical Review, C.88, S.346, 1973, s. 81-91.

SWEETMAN, John, The Crimean War, Osprey Publishing, Oxford 2001.

THOMAS, Robert H. G. - Richard Scollins, The Russian Army of the Crimean War 185456, Ed. Martin Windrow, Osprey Military, Oxford 1991.

TUNCER, Hüner, Doğu Sorunu ve Büyük Güçler (1853 - 1878), Osmanlı'nın Kader Yılları, Ümit Yayınclık, Ankara 2003.

TÜRKGELDİ, Ali Fuat, Mesail-i Mühimme-i Siyasiye, C.1, Haz.: Bekir Sttk1 Baykal, Türk Tarih Kurumu, Ankara 1987. 
YILDIZ, Gültekin, Neferin Adl Yok (Zorunlu Askerliğe Geçiş Sürecinde Osmanlı Devleti'nde Siyaset, Ordu ve Toplum, 1826 - 1839), Kitabevi Yaymları, İstanbul 2009.

Yüzbaşı Fevzi, 1853 - 1856 Türk Rus Harbi ve Kırım Seferi, Devlet Matbaası, İstanbul 1927. 
EK: Satın Alınan Mühimmata İlişkin Nakliye Masrafları (Frank)

\begin{tabular}{|c|c|c|c|c|c|c|c|c|}
\hline & 镸焉 & & & $\frac{2}{2}$ & $\frac{n}{2}$ & $\frac{7}{2}$ & हे & 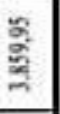 \\
\hline & 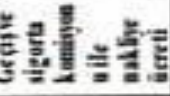 & & & 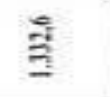 & $\overline{\bar{i}}$ & 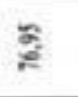 & 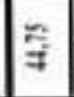 & $\frac{\vec{y}}{\Rightarrow}$ \\
\hline & 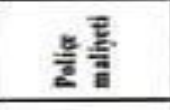 & & & $:$ & - & - & $\equiv$ & -1 \\
\hline & 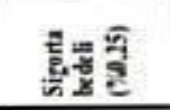 & & & 产 & $z$ & $=$ & 5 & $\begin{array}{l}\text { 势 } \\
\Rightarrow\end{array}$ \\
\hline & 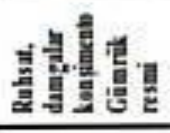 & & & ఫ్ & $\frac{3}{8}$ & $\stackrel{3}{2}$ & 8 & $\frac{B}{2}$ \\
\hline 战 & 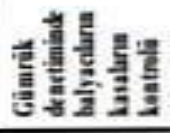 & & & $\underset{I}{Z}$ & $\Xi$ & $\dot{z}$ & 2 & $\underset{2}{2}$ \\
\hline $\begin{array}{l}\text { HISTORY } \\
\text { STUDIES } \\
55\end{array}$ & 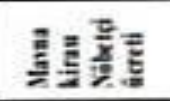 & & & है & 올 & & $\overline{\mathrm{g}}$ & 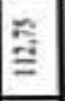 \\
\hline volume 8 & 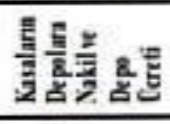 & & & . & . & $\exists$ & $=$ & . \\
\hline $\begin{array}{l}\text { Issue } 4 \\
\text { December } \\
2016\end{array}$ & 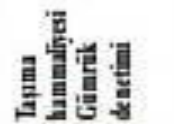 & & & 谙 & 엄 & $\partial$ & $\underline{\underline{z}}$ & $\frac{9}{2}$ \\
\hline & 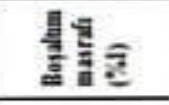 & 2 & $\xi$ & E & 言 & $E$ & 3 & $\begin{array}{ll}2 \\
2 \\
2\end{array}$ \\
\hline & 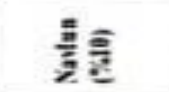 & : & $\frac{7}{2}$ & 产 & 三ે & $\hat{E}$ & $\supseteqq$ & 吾 \\
\hline & 咅 & 8 & $\bar{z}$ & $\begin{array}{l}5 \\
\frac{5}{5} \\
\end{array}$ & 를 & $\bar{E}$ & 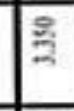 & 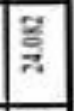 \\
\hline & 镸司 & $\$ 7$ & & & & $=$ & $\approx$ & 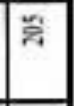 \\
\hline & 橧 & 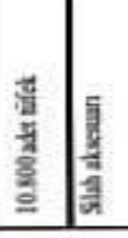 & & & & 要: & 要 & 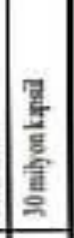 \\
\hline & 를 & $\underline{\underline{E}}$ & $\begin{array}{l}\bar{z} \\
\underline{5} \\
\underline{5}\end{array}$ & $\begin{array}{l}\overline{\underline{z}} \\
\frac{\pi}{\pi}\end{array}$ & 量 & 萻 & $\frac{2}{2}$ & $\underline{\underline{\underline{a}}}$ \\
\hline & 焉而 & 8 & 量妾新 & 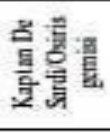 & 部票 & 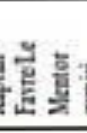 & & 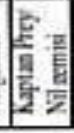 \\
\hline
\end{tabular}


EK: Fransa'dan Gemi Vasıtasıyla Satın Alınan Mühimmata İlişkin Nakliye Masrafları (Frank)- (Devam) $)^{65}$

\begin{tabular}{|c|c|c|c|c|c|c|c|c|c|}
\hline 高高 & \multicolumn{2}{|c|}{ 音 } & 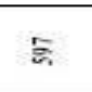 & 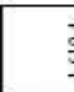 & 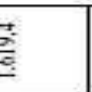 & \multicolumn{4}{|c|}{$\vec{E}$} \\
\hline 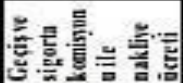 & \multicolumn{2}{|c|}{$\equiv$} & $=$ & 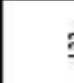 & 2 & \multicolumn{4}{|c|}{$\Leftrightarrow$} \\
\hline 童最 & \multicolumn{2}{|c|}{$\circ$} & - & . & 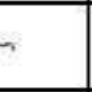 & \multicolumn{4}{|c|}{$\alpha$} \\
\hline 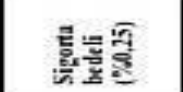 & \multicolumn{2}{|c|}{ 官 } & $\Rightarrow$ & 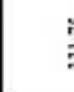 & $E$ & \multicolumn{4}{|c|}{$\Xi$} \\
\hline 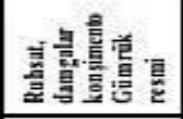 & \multicolumn{2}{|c|}{$\xi$} & $\overline{\underline{x}}$ & 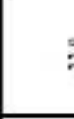 & 6 & \multicolumn{4}{|c|}{$\stackrel{5}{3}$} \\
\hline 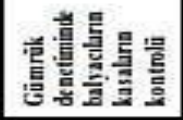 & \multicolumn{2}{|c|}{$\therefore$} & $\frac{5}{7}$ & 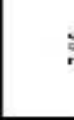 & 3 & \multicolumn{4}{|c|}{$\cong$} \\
\hline 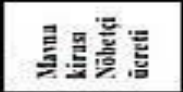 & \multicolumn{2}{|c|}{ 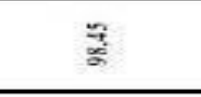 } & $\cong$ & 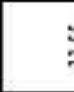 & 6 & \multicolumn{4}{|c|}{ 要 } \\
\hline 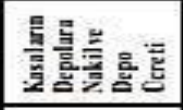 & \multicolumn{2}{|c|}{$\approx$} & $\beth$ & 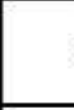 & · & \multicolumn{4}{|c|}{. } \\
\hline 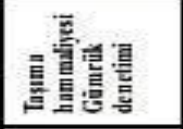 & \multicolumn{2}{|c|}{$\underline{\tilde{I}}$} & $\stackrel{3}{\pi}$ & 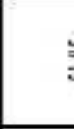 & 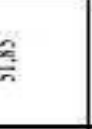 & \multicolumn{4}{|c|}{$\overline{\vec{x}}$} \\
\hline 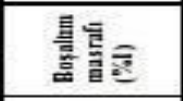 & $\overline{\bar{x}}$ & $\begin{array}{ll}5 \\
\end{array}$ & 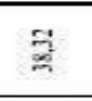 & 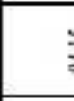 & 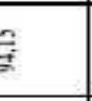 & \multicolumn{4}{|c|}{ है } \\
\hline 㗝言 & 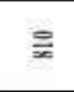 & 商 & है & 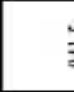 & 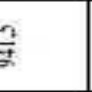 & \multicolumn{4}{|c|}{$\frac{3}{3}$} \\
\hline 吾 & $\frac{\mathrm{s}}{\infty}$ & 总 & 출 & 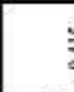 & 5 & \multicolumn{4}{|c|}{ 莒 } \\
\hline 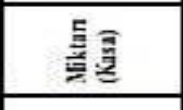 & 8 & $\cong$ & $\Rightarrow$ & $=$ &. & $=$ & $\Rightarrow$ & 5 & $=$ \\
\hline 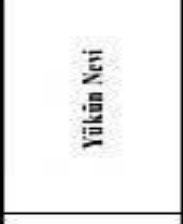 & 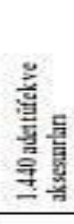 & 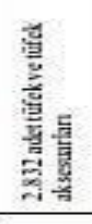 & 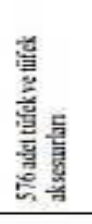 & 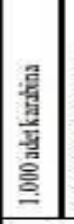 & 竞 & 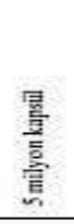 & $\mid$ & 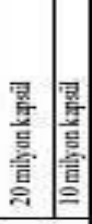 & 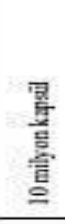 \\
\hline 咅 & $\bar{s}$ & $\frac{2}{a}$ & $\frac{\bar{z}}{\partial}$ & 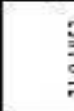 & 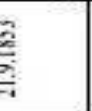 & $\frac{a}{a}$ & & $\vec{z}$ & 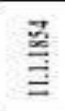 \\
\hline$E_{E}$ & & & & & & & & & \\
\hline
\end{tabular}

6511 Temmuz ve 15 Temmuz 1853 Tarihlerinde gönderilen Leonidas ve Eurotas isimli gemilerin navlun bedelleri kendileri tarafından karşılanmışır. 21 Eylül 1853 Tarihinde Thabor isimli gemiyle gönderilen eşyalardan Paris Sefiri Veli Paşa tarafından siparişi verilen 12 kasa çantanın Paris'ten Marsilya'ya nakli ve oradan gemiye bindirilmesi 257,30 franka mal olmuştur.

Kaynak: BOA., HR. SFR4. 10/4, 9 Temmuz 1853 (1269 L 2); BOA., HR. SFR4. 10/6, 3 Eylül 1853 (1269 Za 29); BOA., HR. SFR4. 10/7, 25 Ekim 1853 (1270 M 22); BOA., HR. SFR4. 10/9, 2 Ocak 1854, (1270 R 2). 